\title{
Towards a Regulatory Design for Reducing Emissions from Agriculture: Lessons from Australia's Carbon Farming Initiative
}

\author{
Jonathan Verschuuren \\ Professor of International and European Environmental Law, \\ Tilburg University, and Marie Sklodowska-Curie Fellow, University of Sydney \\ j.m.verschuuren@tilburguniversity.edu
}

\begin{abstract}
The land sector is essential to achieve the Paris Agreement's goals. Agriculture and land use contribute between 20 and 25 per cent of global greenhouse gas emissions. The Paris Agreement's aim to keep the average global temperature rise between 1.5 and 2 degrees Celsius implies that drastic emission cuts from agriculture are needed. The sequestration potential of agriculture and land use offers an important mechanism to achieve a transition to net-zero carbon emissions worldwide. So far, however, states have been reluctant to address emissions from, and sequestration by, the agricultural sector. Some states that have or are setting up a domestic emission-trading scheme allow for the generation of offsets in agriculture, but only to a limited extent. Australia is the only country that has a rather broad set of methodologies in place to award credits to farmers for all kinds of carbon-farming projects. This article reviews the experience with the Australian model so far, with the objective of articulating transferable lessons for regulatory design aimed at reducing greenhouse gas emissions from agriculture. It finds that it is possible to regulate for the reduction of emissions from agriculture
\end{abstract}

* This project has received funding from the European Union's Horizon 2020 research and innovation programme under the Marie Sklodowska-Curie grant agreement No. 655565. I wish to thank everyone at the University of Sydney's Australian Centre for Climate and Environmental Law for their support and assistance, especially Rosemary Lyster, Ed Couzens, Kate Owens, Celeste Black, Tim Stephens, and Andrew Edgar. I also owe thanks to all the stakeholders who so generously gave their time to answer my questions, often in quite lengthy interviews. This project could not have been carried out without their contribution. I also wish to thank the journal's six referees for their detailed feedback on an earlier version of this article. Any errors remaining are my own. The data used here are current as at 1 June 2016. 
and for increased sequestration in agricultural soils and in vegetation on agricultural lands, provided that certain conditions are met. Regulation must focus on individual projects at farms, based on a long-term policy that has a wider focus than just emission reduction. Such projects must comply with climate-smart methodologies that ensure the delivery of real, additional, measurable, and verifiable emission reductions and also foster long-term innovation and create economic, social, and environmental cobenefits. Moreover, a robust and reliable MRV system must be put in place.

\section{Keywords}

Paris Agreement - climate-smart agriculture - carbon farming - carbon offsets emissions from agriculture - soil carbon - carbon sequestration - emission trading

\section{Contents}

1 Introduction 3

2 Regulating Emissions from Agriculture Around the World 6

3 Australia's Carbon Farming Initiative 11

3.1 Science Background to the CFI 11

3.1.1 Australia's Greenhouse Gas Emissions 11

3.1.2 Emissions from Agriculture 13

3.2 Current Regulatory Framework for Emission Reductions from

Agriculture 14

3.2.1 Introduction: Rise and Fall of Emission Trading in Australia 14

3.2.2 The CFI Act in More Detail 16

3.2.2.1 Projects 16

3.2.2.2 Methodology Determinations 16

3.2.2.3 Issuing AccUs 20

3.2.2.4 Auctions and Carbon-Abatement Contracts 21

3.2.2.5 Compliance 23

3.2.3 Adding a Cap: The 'Safeguard Mechanism' 23

4 Experiences with the CFI Act 24

4.1 Methodology 24

4.2 Introduction: Data on, and Examples of, Carbon-Farming Projects 25

4.2.1 Number of On-Farm CFI/ERF Projects 25

4.2.2 Illustrative CFI/ERF Projects Run by Farmers 28

4.2.2.1 Methane Capture in Piggeries 28

4.2.2.2 Sequestration in Grazing Land 29 
4.2.2.3 Reforestation by Mallee Plantings 30

4.2.2.4 Avoided Deforestation 30

4.3 Stakeholders' Experiences with Carbon Farming in Australia 31

4.3.1 Farmers' Motivation to Run Projects under the CFI/ERF 31

4.3.1.1. Slow Start, Growing Interest, and Attitude Change $3^{1}$

4.3.1.2 An Aging Sector 32

4.3.1.3 Small Farms 33

4.3.2 The Role of Consultants 34

4.3.3 CFI v. ERF: Carbon Market or Fixed Price 35

4.3.4 Funding Project Investments 36

4.3.5 Administration and Compliance 38

4.3.5.1 Competent Authority's Perspective 38

4.3.5.2 Farmers'Perspective 39

4.3.6 Scope of the Projects: Method Aims 40

4.3.6.1 Development of Methodology Determinations for the Agricultural Sector 40

4.3.6.2 Mitigation or Climate-Smart Agriculture? 42

4.3.7 Results of CFI/ERF for the Environment and for the Individual

Farmer 42

4.3.8 Future Production Increases and Additional Emission Cuts:

What Role for CFI/ERF? 44

4.3.8.1 Financing Carbon Farming: Private Carbon Market or Government Scheme? 44

4.3.8.2 Broadening the Scheme beyond Mitigation? 46

4.3.8.3 What About Food Security? 46

4.4 Conclusions from Empirical Research 48

5 Conclusion: Lessons for Regulatory Design Aimed at Reducing Emissions from Agriculture 49

Under the Paris Agreement, in order to hold the increase in the global average temperature to well below 2 degrees Celsius above pre-industrial levels, a balance needs to be achieved between anthropogenic emissions by sources and removals by sinks of greenhouse gases in the second half of this century. ${ }^{1}$ Although the Paris Agreement hardly mentions agriculture, both agriculture and land use are sectors that are important for the achievement of the

1 Paris Agreement, art. 4. 
aforementioned goal. ${ }^{2}$ After decades of neglect, the international community is slowly starting to acknowledge this fact. A May 2016 UNFCCC Secretariat survey of states' INDCs shows that 74 per cent of the 138 INDCs submitted cover agriculture. ${ }^{3}$ However, policies are generally lacking and need to be developed from scratch.

In its Fifth Assessment Report, the IPCC's Working Group III concludes that the AFOLU sector (agriculture, forestry, and other land use) is responsible for just under a quarter $\left(\sim 10-12 \mathrm{GtCO}_{2}\right.$ eq./yr) of anthropogenic greenhouse gas emissions. ${ }^{4}$ Usually, a distinction is made between non- $\mathrm{CO}_{2}$ emissions, in particular methane emitted by livestock and from rice cultivation, and nitrous oxide from the use of synthetic fertilizers and the application of manure to soils and pasture. The global warming potentials of methane and nitrous oxide are, respectively, 25 and 300 times that of carbon dioxide. Carbon dioxide emissions from agriculture are mainly caused by deforestation and peatland drainage. Emissions from agriculture have been rising on a yearly basis since 1990, although with important regional differences (they went down in Europe and up in Asia). ${ }^{5}$ So far, these emissions have not been specifically addressed under the UnfCCC, Kyoto Protocol, or Paris Agreement. ${ }^{6}$ Domestic regulators have also been reluctant to address agricultural emissions. ${ }^{7}$

It is expected that under a business-as-usual scenario, emissions from agriculture will rise sharply over the coming years and decades because of an expected increase of 40 per cent or more in the demand for agricultural products,

2 Joeri Rogelj, Michel den Elzen, Niklas Höhne, Taryn Fransen, Hanna Fekete, Harald Winkler, Roberto Schaeffer, Fu Sha, Keywan Riahi, and Malte Meinshausen, 'Paris Agreement Climate Proposals Need a Boost to Keep Warming Well Below $2{ }^{\circ} \mathrm{C}$ ', 534 Nature 631 (2016). See also Jonathan Verschuuren, 'The Paris Agreement on Climate Change: Agriculture and Food Security', 7(1) European Journal of Risk Regulation 54-57 (2016).

3 UNFCCC Secretariat, 'Aggregate Effect of the Intended Nationally Determined Contributions: An Update: Synthesis Report by the Secretariat', FCCC/CP/2016/2 (2016), at 32.

4 P. Smith et al., 'Agriculture, Forestry and Other Land Use (AFOLU)', in Climate Change 2014: Mitigation of Climate Change: Contribution of Working Group III to the Fifth Assessment Report of the Intergovernmental Panel on Climate Change (Cambridge, uK: Cambridge University Press, 2014), at 816.

5 Ibid., at 823 .

6 Verschuuren, supra note 2; and Jonathan Verschuuren, 'Climate Change and Agriculture under the United Nations Framework Convention on Climate Change and Related Documents', in Research Handbook on Climate and Agricultural Law, edited by Mary Jane Angelo and Anel DuPlessis (Chelthenham, UK: Edward Elgar, 2016).

7 The IPCC points to 'implementation challenges, including institutional barriers and inertia related to governance issues'; in Smith et al., supra note 4 , at 817 . 
mainly in Asia. ${ }^{8}$ The causes of the rise in demand include the growing world population (from seven billion today to nine billion in 2050) and dietary changes caused by a wealthier middle class in countries such as China and India. In Australia, the agrifood sector expects to be able to increase its production by 77 per cent from 2007 levels by 2050 to meet this greater Asian demand. ${ }^{9}$

To address the expected rise in emissions from agriculture, many developed countries are in the process of integrating the land-use sector into their climate policies. The European Union, for example, will require the agricultural and land-use sectors to contribute substantially to achieving the EU's 2030 emission-reduction target. ${ }^{10}$ As explained below, the only country that already has a discrete regulatory instrument in place to reduce emissions from agriculture is Australia. Its Carbon Farming Initiative (CFI) is now five years' old. Despite the country's much criticized poor overall climate policy, the CFI has spurred farmers into action and, therefore, potentially provides the rest of the world with a model to reduce emissions from agriculture. This article reviews the experiences with the Australian model so far, with the objective to articulate transferable lessons for regulatory design aimed at reducing greenhouse gas emissions from agriculture.

In this article, I rely partly on desk research and partly on empirical research into stakeholders' experiences with the Australian scheme. First, a study of the relevant legal and policy documents was conducted to find out the regulatory design of the Australian instrument and its broader legal and policy background. Then, relevant stakeholders were interviewed, and case studies into selected projects were carried out, to discover the experiences of these stakeholders with the scheme, as well as the pros and cons of the regulatory approach. Stakeholders interviewed included the government authorities involved, such as the main regulator and administrator of the CFI, agricultural business organizations, consultants working with individual farmers ('carbon agents'), and financial institutions that finance farming businesses. ${ }^{11}$ It should be noted that the article focuses only on the CFI's impact on farming. It does

Bruce Campbell, Wendy Mann, Ricardo Meléndez-Ortiz, Charlotte Streck, and Timm Tennigkeit, Agriculture and Climate Change: A Scoping Report (Washington, DC: Meridian Institute, 2011), at 3 .

9 Climate Change Authority, Reducing Australia's Greenhouse Gas Emissions: Targets and Progress Review - Final Report (Canberra: Commonwealth of Australia, 2014), at 305.

10 European Council, '2030 Climate and Energy Policy Framework', E U CO 169/14 (2014), at 5.

11 The methodology of the empirical research is explained in more detail in Section 4.1, below. 
not assess its impact on other sectors, nor does it assess the broader Australian emission-reduction framework.

The article is structured as follows. Section 2 gives a short introduction to current regulatory approaches to reducing emissions from agriculture by discussing several examples from around the world, as well as introducing the wider context of climate-smart agriculture. Section 3 gives a detailed description of the current Australian legislation on reducing emissions from agriculture, as well as the science background of the CFI. Section 4 reports on the findings of the empirical research. Section 5 draws lessons from the Australian model.

$\mathbf{2}$

\section{Regulating Emissions from Agriculture around the World}

The most common policy instrument used to reduce greenhouse gas emissions is emission trading. ${ }^{12}$ Emission-trading schemes exist in a large number of countries, states, provinces, and cities, ${ }^{13}$ including the $28 \mathrm{EU}$ member states and three associated states (in the form of the EU ETS), ${ }^{14}$ Switzerland (where a linkage with EU ETS is under discussion), ${ }^{15}$ nine states in the northeastern United States (RG I),${ }^{16}$ California, ${ }^{17}$ the Canadian provinces of Quebec

12 Harro Van Asselt, Michael Mehling, and Clarisse Siebert, "The Changing Architecture of International Climate Change Law', in Research Handbook on Climate Change Mitigation Law, edited by Geert van Calster, Wim Vandenberghe, and Leonie Reins (Cheltenham, UK: Edward Elgar, 2015), at 20.

13 For information on all of these emissions trading schemes, see the case study reports: Institute for Climate Economics, Put a price on carbon: different models of carbon pricing around the world (Paris: I4CE, 2015), <www.i4ce.org/go_project/put-a-price-on-carbon -different-models-of-carbon-pricing-around-the-world/>.

14 Directive 2003/87/EC of the European Parliament and of the Council of 13 October 2003 establishing a scheme for greenhouse gas emission allowance trading, oJ L 275/32 (2003).

15 Federal Act of 23 December 2011 on the Reduction of $\mathrm{CO}_{2}$ Emissions $\left(\mathrm{CO}_{2} \mathrm{Act}\right)$; see $<\mathrm{www}$ .admin.ch/opc/en/classified-compilation/20091310/index.html>. In January 2016, Switzerland and the EU reached an agreement on linkage of the Swiss and the EU ETS; see Environment Ministry press statement $<$ www.bafu.admin.ch/dokumentation/medienin formation/oog62/index.html?lang=en\&msg-id=60425>.

16 This ETS is based on regulations in each of the participating states; see the RGGI's website, <www.rggi.org/design/regulations >.

17 Regulation for the California Cap on Greenhouse Gas Emissions and Market-Based Compliance Mechanisms, title 17, CCR, sections 95801-96022, <www.arb.ca.gov/cc/ capandtrade/capandtrade/unofficial_ct_030116.pdf>. 
(linked to the California ETS), ${ }^{18}$ Ontario (intended to be linked with the California ETS as well as the Quebec ETS), ${ }^{19}$ and Alberta, ${ }^{20}$ seven regions in China (where the aim is to scale up to the national level in 2017), ${ }^{21}$ South Korea, ${ }^{22}$ Kazakhstan, ${ }^{23}$ New Zealand, ${ }^{24}$ and the Japanese cities of Saitama and Tokyo. ${ }^{25}$ Australia set up a national ETS in 2012; it was repealed in 2015, before trading could commence. ${ }^{26}$

None of these schemes directly apply to emissions from agriculture, although some allow offsets from agriculture, as will be explained below. In New Zealand, it was initially planned to require farmers to surrender allowances under the ETS, but this was dropped in 2012 following a successful lobbying effort by the agricultural sector. ${ }^{27}$

18 The Québec Cap and Trade System for Greenhouse Gas Emissions Allowances; see <www .mddelcc.gouv.qc.ca/changements/carbone/documentation-en.htm\#regulations >.

19 The Climate Change Mitigation and Low Carbon Economy Act was adopted on 18 May 2016 and the Cap and Trade Regulation took effect on 1 July 2016; see <www.ontario.ca/ page/cap-and-trade>.

20 Specified Gas Emissions Regulation, Alberta Regulation 139/2007; see <http://aep.alber ta.ca/climate-change/guidelines-legislation/specified-gas-emitters-regulation/default .aspx $>$.

21 See, in greater detail, Huizhen Chen, Towards a Market-Based Climate Policy in China? A Legal Perspective on the Design and Application of Greenhouse Gas Emissions Trading (doctoral thesis University of Maastricht, 2015), and Xiaoyi Jiang, 'Climate Change and Energy Law', in Research Handbook on Chinese Environmental Law, edited by Tianbao Qin (Cheltenham: Edward Elgar 2015) 162-95.

22 Act on Allocation and Trading of Greenhouse Gas Emissions Allowances (2012). Trading under the ETS started in 2015. See <http://eng.me.go.kr/eng/web/index.do?menuId $=450$ \& findDepth $=1>$.

23 Based on amendments to the Kazakhstan Ecological Code (2011), and largely modelled on the EU ETs. See $<$ http://adilet.zan.kz/eng/docs/Ko700oo212_>.

24 Climate Change Response (Emissions Trading) Amendment Act 2008, Act 2008 No. 85; see $<$ www.legislation.govt.nz/act/public/2008/0085/latest/DLM1130932.html $>$.

25 Marion Afriat, Katherine Rittenhouse, and Katie Kouchakji, 'Tokyo: A Case Study on Emissions Trading', in Institute for Climate Economics, supra note 13.

26 Carbon Credits (Carbon Farming Initiative) Act 2011, as amended in 2014. See Climate Change Authority, supra note 9, at $77-83$. Australia's CFI remained in place as a standalone instrument following the repeal of the ETS.

27 David Bullock, 'Emissions Trading in New Zealand: Development, Challenges and Design', 21(4) Environmental Politics 657 (2012), at 661. Under the Climate Change Response (Emissions Trading and Other Matters) Amendment Act 2012, the obligation to surrender allowances for agricultural emissions was suspended. What remained is the requirement for farmers in some sectors (meat processors, dairy processors, nitrogen fertilizer manufacturers and importers, and live animal exporters) to report biological emissions from 
The inclusion of farming in an ETS is considered problematic because of the difficulty of measuring emissions and emission reductions at the farm level. Non- $\mathrm{CO}_{2}$ emissions from livestock and the use of fertilizers can fairly easily be estimated at the national level ${ }^{28}$ using uniform emission factors (per animal, per unit of arable land, etc.). ${ }^{29}$ Non- $\mathrm{CO}_{2}$ emissions from agriculture are thus assessed and regulated at a sector-wide level, on the basis of IPCC instructions for calculating emissions from agriculture ${ }^{30}$ Farm-level emissions are much more difficult to measure because of the variety of factors involved (the diet of animals, tillage intensity, soil composition, regional weather systems, fertilizerapplication methods, etc.). ${ }^{31}$ Even more difficult to estimate are agriculture's $\mathrm{CO}_{2}$ emissions.

The use of uniform emission criteria to overcome farm-level measurement problems has the disadvantage that it diminishes the incentive of individual farmers to change their practices; it is also more vulnerable to fraud because of the disconnect with real emissions. ${ }^{32} \mathrm{~A}$ farm-specific monitoring and measurement system would be very expensive. ${ }^{33}$ Australia, for one, has more than

methane and nitrous oxide that are produced on-farm. See <www.climatechange.govt.nz/ emissions-trading-scheme/ets-amendments/>.

28 Peter Wehrheim and Asger Strange Oleson, 'Land Use, Land Use Change and ForestryHow to Enter the Climate Impact of Managing Biospheres and Wood into the Eu's Greenhouse Accounting', in Research Handbook on Climate Change Mitigation Law, edited by Geert van Calster, Wim Vandenberghe, and Leonie Reins (Cheltenham, U K: Edward Elgar, 2015), at 304 .

29 Andrew Macintosh and Lauren Waugh, 'An Introduction to the Carbon Farming Initiative: Key Principles and Concepts', 29(6) Environmental and Planning Law Journal 439 (2012), at 445-6.

$30 \quad$ IPCC, Revised 1996 IPCC Guidelines for National Greenhouse Gas Inventories (see especially the chapter on agriculture in volume $2,<$ www.ipcc-nggip.iges.or.jp/public/gl/invs5c .html >). See, in more detail, Verschuuren, supra note 6, at 31-34. In the EU, emissions from agriculture have been included in the Effort Sharing Decision (Decision 406/2009/EC of the European Parliament and of the Council of 23 April 2009 on the Effort of Member States to Reduce their Greenhouse Gas Emissions to Meet the Community's Greenhouse Gas Emission Reduction Commitments up to 2020, oJ L 140/136 (2009)), which means that agricultural emissions, together with emissions from other non-ETs sectors, are subject to an overall reduction target for each member state. Individual member states are free to choose how and where they are achieving this overall target; see Wehrheim and Oleson, supra note 26 , at 313 .

31 Hugh Saddler and Helen King, 'Agriculture and Emissions Trading: The Impossible Dream?' (Discussion Paper Series No. 102, The Australia Institute, 2008), at 102.

32 Macintosh and Waugh, supra note 29. Ibid. 
123,000 agricultural businesses. ${ }^{34}$ Measuring their greenhouse gas emissions and their carbon sequestration individually could turn into an administrative nightmare.

Under some of the emission-trading schemes mentioned above, credits can be generated from agriculture to be used as offsets by industries required to submit emission allowances. This is the case in California, Quebec, Alberta, Ontario, and the RGGI scheme; and it was the case in the Australian scheme. Under California's ETS, two types of agricultural offset project are accepted, each aimed at reducing methane emissions: biogas systems in dairy cattle and swine farms, ${ }^{35}$ and rice-cultivation projects. ${ }^{36}$ Alberta accepts a wide range of agricultural offset projects: nitrous-oxide emission reductions, biofuel production and usage, waste biomass projects, several renewable-energy production and usage projects, conservation cropping, several types of project involving beef production (low residual feed intake, reduced age at harvest, reduced days on feed), projects aimed at reducing emissions from dairy cattle, and biogas production. ${ }^{37}$

In some countries, agricultural offsets are linked to other regulatory instruments aimed at reducing greenhouse gas emissions. Japan has an elaborate offset-credit system (J-VER), linked to various, mostly voluntary, programmes for industry and the energy sector. ${ }^{38}$ The scheme allows individuals, businesses, and local governments to invest in offset projects, with the aim not only to reduce emissions but also to expand job opportunities, support domestic project proponents, and vitalize local industries. ${ }^{39}$ Project registration and credit issuance requires verification by accredited bodies under the ISO14065 accreditation programme. Four agricultural methodologies were adopted under this system: mitigation of nitrous-oxide emissions from tea-land soil by application

34 Australian Bureau of Statistics, data for 2015, <www.abs.gov.au/ausstats/abs@.nsf/mf/ 4627.0>.

35 The methodology for the implementation of these systems has been laid down in the Compliance Offset Protocol Livestock Projects: Capturing and Destroying Methane from Manure Management Systems, adopted by the California EPA's Air Resources Board on 14 November 2014, <www.arb.ca.gov/regact/2014/capandtrade14/ctlivestockprotocol.pdf >.

36 See Compliance Offset Protocol Rice Cultivation Projects, adopted 25 June 2015, <www .arb.ca.gov/cc/capandtrade/protocols/rice/riceprotocol2015.pdf>.

For more information, see the Alberta Ministry for Agriculture and Forestry's website, $<$ www1.agric.gov.ab.ca/\$Department/deptdocs.nsf/all/cl11618>.

38 Marion Afriat, Katherine Rittenhouse, and Katie Kouchakji, 'Japan: A Case Study on Carbon Pricing', in Institute for Climate Economics, supra note 13.

39 See the government website on the offset credit scheme, <www.j-ver.go.jp/e/about_jver .html>. 
of chemical fertilizers containing a nitrification inhibitor; mitigation of methane emissions from flooded rice paddies by application of composts instead of rice straws; reduction in emissions from livestock-excrement management through changed management methods; and reduction in emissions from the disposal of pig excreta through replacement of conventional feed with lowprotein formula feed.$^{40}$ In another example, under South Africa's draft Carbon Tax Bill, ${ }^{41}$ the agricultural sector will be exempt from carbon taxes until at least $2020 .{ }^{42}$ Instead, liable entities will be able to generate offsets in the agricultural sector. Eligible offset projects aim to restore subtropical thickets, forests, and woodlands, restore and manage grasslands, and support small-scale afforestation, biomass-energy production, anaerobic biogas digesters, and reduced tillage. ${ }^{43}$

As a final introductory remark, it should be noted that the carbon-farming initiatives mentioned above are primarily aimed at mitigation of greenhouse gas emissions. They are not aimed at improving the resilience of the agricultural sector to the impacts of climate change. As such, carbon farming has a narrower scope than climate-smart agriculture (CSA). CSA is an approach to developing the technical, policy, and investment conditions to achieve sustainable agricultural development for food security under climate change, and is composed of three main pillars: sustainably increasing agricultural productivity and incomes; adapting and building resilience to climate change; and reducing or removing greenhouse gas emissions. ${ }^{44}$ Carbon-farming initiatives, given their focus on greenhouse gas emission reductions from agriculture and increased carbon sequestration in agricultural soils and vegetation, are important elements of a CSA regulatory regime, but must be complemented by instruments aimed at adaptation and food security. In practice, increased resilience is often a side effect of carbon-offset projects in agriculture, particularly

$40 \quad$ Ibid.

41 The Draft Carbon Tax Bill was published in November 2015; see <www.treasury.gov.za/ public comments/CarbonTaxBill2015/Carbon Tax Bill final for release for comment.pdf>. The new system of carbon taxes is expected to take effect in January 2017. Draft Carbon Offset Regulations were published on 20 June 2016; see <www.treasury.gov.za/public comments/CarbonTaxBill2016/Carbon offset Regulations.pdf $>$.

42 Michael Kidd, 'Climate Change and Agriculture', in Climate Change Law and Governance in South Africa, edited by Tracy-Lynn Humby, Louis Kotzé, Olivia Rumble, and Andrew Gilder (Cape Town: Juta, 2016), at Ch. 17, p. 10.

43 Olivia Rumble, Andrew Gilder, and Mansoor Parker, 'Carbon Pricing in South Africa', in Climate Change Law and Governance in South Africa, edited by Tracy-Lynn Humby, Louis Kotzé, Olivia Rumble, and Andrew Gilder (Cape Town: Juta, 2016), at Ch. 20, p. 35 . FAO, Climate Smart Agriculture Sourcebook (Rome: FAO, 2013), at ix. 
of projects aimed at increased carbon sequestration in soils and planting vegetation on agricultural lands, as they lead to more fertile soils and better moisture retention and thus to increased production, better water management, and reduced fertilizer use. A recent literature review found that increasing soil carbon can have profound effects on soil quality and agro-ecosystem productivity. Soil carbon plays an important role in maintaining soil structure, improving soil-water retention, fostering healthy soil microbial communities, and providing fertility for crops. ${ }^{45}$ Also, soil-carbon projects are often part of the introduction of wider regenerative practices that focus on soils, water, and biodiversity. ${ }^{46}$ In my research for this article, I thus paid attention to the potential adaptation and food-security co-benefits of Australian carbon-farming projects, as seen below.

\section{$3 \quad$ Australia's Carbon Farming Initiative}

This section gives a detailed description of current Australian legislation on reducing emissions from agriculture. But first I will give a brief sketch of the science background to the legislation.

\subsection{Science Background to the CFI}

\subsubsection{Australia's Greenhouse Gas Emissions}

Australia is a high-emitting country in terms of both total and per-capita emissions. ${ }^{47}$ In 2015, Australia's emissions, including LULUCF, totaled 535.7 Mt $\mathrm{CO}_{2}$ eq. (529.2 $\mathrm{Mt} \mathrm{CO}_{2}$ eq. excluding LULUCF) ${ }^{48} 2.5$ per cent below 2000

45 Daniel Kane, Carbon Sequestration Potential on Agricultural Lands: A Review of Current Science and Available Practices (Washington, DC: National Sustainable Agriculture Coalition, 2015), at 18. See also, among many others, Rattan Lal, 'Societal Value of Soil Carbon', 69(6) Journal of Soil and Water Conservation 186A (2014); F. Alliaume, W.A.H. Rossing, M. García, K.E. Giller, and S. Dogliotti, 'Changes in Soil Quality and Plant Available Water Capacity Following Systems Re-design on Commercial Vegetable Farms', 46 European Journal of Agronomy 10 (2013).

46 In Australia, for example, there is growing support for such programmes as 'soils for life' and 'healthy soils'. Case studies show remarkable results of reduced carbon emissions, better growing conditions, more water availability, and more biodiversity; see <www .soilsforlife.org.au> and <www.healthysoils.com.au> .

47 Climate Change Authority, supra note 9, at 69.

48 Department of the Environment, Quarterly Update of Australia's National Greenhouse Gas Inventory: December 2015 (Canberra: Commonwealth of Australia, 2016), at 7. 
levels. ${ }^{49}$ Australia has the highest emissions per capita of all developed countries. ${ }^{50}$ On average, Australians emit $17.3 \mathrm{t} \mathrm{CO}_{2}$ eq. per person (the corresponding figure for the $\mathrm{EU}$ is $6.7 \mathrm{t} \mathrm{CO}_{2}$ eq.). ${ }^{51} \mathrm{In}$ Australia, per capita emissions went up 7 per cent between 1990 and 2014. ${ }^{52}$ By comparison, they went down in the United States and the EU by 16 and 27 per cent, respectively, over the same period. ${ }^{53}$ Australia is responsible for about 1.3 per cent of the world's greenhouse gas emissions, making it the fifteenth highest emitter in the world. ${ }^{54}$ The Climate Change Performance Index, which rates the climate-protection performance of 58 countries, which together are responsible for more than 90 per cent of global energy-related $\mathrm{CO}_{2}$ emissions, has Australia in the category of 'very poor', near the bottom of the list; only Kazakhstan and Saudi Arabia perform worse. ${ }^{55}$

Most publications on Australia's climate change policies begin by referring to the dominance of coal in the country by way of an explanation of why such policies remain underdeveloped. ${ }^{56}$ Mining contributes about 8 per cent to GDP. ${ }^{57}$ Australia is the fourth largest coal producer (after China, the United States, and India). ${ }^{58}$ Australia, which has vast coal reserves, ${ }^{59}$ was the world's largest coal exporter until 2011, when it was overtaken by Indonesia. ${ }^{60}$ The fact that Australia's economic growth has stayed above the OECD average

49 Ibid., at 34 .

$50 \quad$ Ibid., at 69 .

51 Jos G.J. Olivier, Greet Janssens-Maenhout, Marilena Muntean, and Jeroen A.H.W. Peters, Trends in Global $\mathrm{CO}_{2}$ Emissions: 2015 Report (The Hague: Netherlands Environmental Assessment Agency, Institute for Environment and Sustainability of the European Commission's Joint Research Centre, 2014), at 31.

52 Ibid.

53 Ibid

54 Climate Change Authority, supra note 9, at 69.

55 Jan Burck, Franziska Marten, and Christoph Bals, The Climate Change Performance Index: Results 2016 (Bonn: Germanwatch and Climate Action Network, 2016), at 9.

56 For example, Hari M. Osofsky and Jacqueline Peel, 'The Role of Litigation in Multilevel Climate Change Governance: Possibilities for a Lower Carbon Future?', 30(4) Environmental and Planning Law Journal 303-28 (2013), at 312-13, as well as Climate Change Authority, supra note 9, at 69 .

57 Australian Bureau of Statistics, Year Book Australia (2012), at 1301.0, <www.abs.gov.au/ ausstats/abs@.nsf/Lookup/by\%2oSubject/1301.0 2012 Main\%2oFeatures Mining\%20 Industry $150>$.

$5^{8}$ World Energy Council, World Energy Resources: Coal (London: World Energy Council, 2013), at 1.3.

59 Ibid., at $1.14-15$.

$60 \quad$ Ibid., at 1.6. 
is attributed largely to a booming mining sector. ${ }^{61}$ Domestic energy supply is generated mainly from coal (at 74 per cent, it is well above the OECD average of 20 per cent) and natural gas (12 per cent). ${ }^{62}$ Renewables account for 14 per cent of domestic energy production. ${ }^{63}$

\subsubsection{Emissions from Agriculture}

Agriculture contributes about 4 per cent to Australia's GDP. ${ }^{64}$ Agriculture accounted for 13 per cent of Australia's emissions (excluding emissions from LULUCF) in 2015. ${ }^{65}$ Three-quarters of this amount was from livestock (mostly enteric fermentation). The remaining one quarter was evenly shared between cropping and savanna burning. ${ }^{66}$ Emissions fluctuate with droughts, during which livestock populations go down. ${ }^{67}$ On average, however, emissions from agriculture have been fairly stable and are expected to grow through to $2030 .{ }^{68}$

Although there has been steady progress in reducing emissions per tonne of livestock produce partly as a result of the pricing mechanism introduced through the CFI (discussed below), substantial increases in the livestock population will cause overall emissions to go up. ${ }^{69}$ Because Australia is in a good position to meet the increasing demand for agrifood commodities in emerging economies in Asia, its production of agrifood may increase by as much as 77 per cent by 2050 from 2007 levels. ${ }^{70}$ The expected production growth is likely to offset emission reductions achieved through the introduction of CSA practices and technologies. ${ }^{71}$

61 Peter Downes, Kevin Hanslow, and Peter Tulip, 'The Effect of the Mining Boom on the Australian Economy' (Research Discussion Paper No. 2014-08, Reserve Bank of Australia, 2014).

62 Australian Energy Regulator, State of the Energy Market 2014 (Melbourne: Australian Energy Regulator, 2014), at 25 and 27 respectively.

63 Ibid., at 27.

64 Australian Bureau of Statistics, supra note 34.

65 Department of the Environment, supra note 48, at 14-15.

66 Climate Change Authority, supra note 9, at 300. Note that emissions from savanna burning are reported under LULUCF rather than under agriculture; see Department of the Environment, supra note 48, at 14 .

67 Ibid., at 301.

68 Ibid., at 301-302. Beef cattle is expected to grow by 28 per cent between 2008 and 2030, sheep by 14 per cent, and poultry by 16 per cent.

69 Ibid.

70 Ibid., at 305 .

71 Ibid. 

from Agriculture

3.2.1 Introduction: Rise and Fall of Emission Trading in Australia In 2011, an Australian emission-trading scheme, following the EU's example, was set up by the federal Clean Energy Act 2011; it took effect on 1 July 2012. ${ }^{72}$ The scheme covered the energy sector, major industrial activities, mining, domestic shipping, domestic aviation, rail transport and non-transport use of fuels, waste (accepted by landfills after 1 July 2012), and fugitive emissions. It covered roughly $5^{0}$ per cent of Australia's emissions. A fixed price was set for the first three years: $\mathrm{AU} \$ 23$ (US\$17) per tonne $\mathrm{CO}_{2}$ eq. for the first year, increasing by 2.5 per cent in each of the two subsequent years. ${ }^{73}$ Trading was to commence on 1 July 2015 , on which date the Australian ETs was to be linked to the EU ETS. A price ceiling and a price floor were set for the first three trading years (until 2018). ${ }^{74}$ The scheme's cap on emissions was set so as to achieve a modest 5 per cent reduction below 2000 levels by 2020, in line with Australia's pledge under the UnfCcc. An independent Climate Change Authority was created to oversee the system and to advise the government on the functioning of the ETS.

Emissions from agriculture, forestry, land use, and landfills (waste accepted before 1 July 2012) were not included in the ETS. There were several reasons for this, including that (1) agricultural, forestry, and land-use sources and sinks are diffuse and involve a large number of actors, which would lead to a sharp increase in the number of liable entities and administration costs; (2) as indicated earlier, emissions and sequestration in these areas of activity are difficult and expensive to monitor and measure, while reverting to simplified estimation methodologies carries the risk of reduced incentives to reduce emissions or opens the door to fraud; and (3), most importantly, there was strong political opposition, with the agriculture and forestry sectors in Australia having considerable political influence. ${ }^{75}$

A separate system, linked to the ETS, was designed for these areas. It was implemented through the Carbon Credits (Carbon Farming Initiative) Act 2011

72 Clean Energy Act 2011, No. 131 (2011). See Elena de Lemos Pinto Aydos, 'Australia's Carbon Pricing Mechanism', in Carbon Pricing, Growth and the Environment, edited by Larry Kleiser, Ana Yábar Sterling, Pedro Herrera, Janet E. Milne, and Hope Ashiabor (Cheltenham: Edward Elgar, 2012), at 261 .

73 At the time (1 July 2012) it was around $€_{19}$, significantly above the Eu's carbon price of $€_{5}$ in 2012.

74 Emma French, "Greenbacks" versus Green Credits: Has the Carbon Farming Initiative Got the Balance Right?', 30(5) Environmental and Planning Law Journal 434 (2013), at 449.

75 Macintosh and Waugh, supra note 29. See also Section 2 above. 
(CFI Act). ${ }^{76}$ The Act allowed for emission offset projects to be proposed, which, once accepted, would lead to the issuance of Australian Carbon Credit Units (ACCUs) for each tonne of $\mathrm{CO}_{2}$ eq. emissions abated or sequestered. Firms in sectors covered by the ETS could purchase ACCUs to meet their obligations. In the fixed-price period (2012-2015), entities regulated under the ETS could count on CFI credits for up to 5 per cent of their emissions; after 2015, there was to be no such limitation. Some of the credits were also recognized under the Kyoto Protocol, and could therefore also be sold on the international carbon market. In addition, the government allocated funds to buy up non-Kyoto credits generated under the CFI Act.

The Clean Energy Act was repealed just two years after its entry into force, in the wake of a change of government. The emission-pricing mechanism was replaced by an Emissions Reduction Fund (ERF, or Direct Action Plan), which took effect in April 2015. Under the ERF, the government purchases emission reductions offered by businesses, local governments, or others, through reverse auctions or other means. The CFI Act was used as the statutory vehicle through which to introduce the ERF's provisions. ${ }^{77}$ The ERF, which covers energy, industry, and transport, essentially extends the CFI model originally designed for agriculture, forestry, and landfills. Instead of a market-based system, the government buys up ACCUs generated through emission-reduction projects. A total budget of AU $\$ 2.55$ billion (US $\$ 1.95$ billion) has been allocated to purchase emission reductions between 2015 and 2019. All CFI projects pre-existing the reform automatically transitioned to the amended Act. CFI methodologies remained largely unchanged. ACcus can also be sold in the private market as voluntary offsets. The Clean Energy Regulator (CER) is the government agency that administers the scheme (auctions, registrations, compliance, etc.). The CFI Act is a very complex piece of legislation with hundreds of provisions, taking up more than three hundred pages of text, plus an additional seventy-nine pages of detailed provisions in the Carbon Credits (Carbon Farming Initiative) Rule 2015 (CFI Rule). ${ }^{78}$

${ }_{76}$ Carbon Credits (Carbon Farming Initiative) Act 2011, No. 101 (2011). See Celeste M. Black, 'Linking Land Sector Activities to Emissions Trading: Australia's Carbon Farming Initiative', in Carbon Pricing, Growth and the Environment, edited by Larry Kleiser, Ana Yábar Sterling, Pedro Herrera, Janet E. Milne, and Hope Ashiabor (Cheltenham: Edward Elgar, 2012), at 185; Andrew Macintosh, "The Carbon Farming Initiative: Removing the Obstacles to its Success', 4(2) Carbon Management 185 (2013); and Macintosh and Waugh, supra note 29.

77 Carbon Farming Initiative Amendment Act 2014, No. 119 (2014).

78 Carbon Credits (Carbon Farming Initiative) Rule 2015 of 13 February 2015. 
3.2 .2 The CFI Act in More Detail

3.2.2.1 Projects

ACCUs can be obtained for both emission-avoidance projects and sequestration projects. Agricultural emission-avoidance projects mostly focus on methane emission reductions: methane capture and combustion from livestock manure and methane emission reduction through manipulation of digestive processes of livestock. Another important emission-avoidance project for the agricultural sector is the application of urease or nitrification inhibitors aimed at reducing fertilizer and manure emissions. The sequestration projects covered are not specifically listed but are broadly defined. ${ }^{79}$ Projects aimed at increased sequestration of carbon in soils are important examples of agricultural projects under this category. Most other sequestration projects are in the category of vegetation, which includes forestry (reforestation, improved forest management, reduced forest degradation, etc.). Although technically not agricultural projects, the latter type of project can be, and indeed are also very relevant for farmers, as they include on-farm revegetation, rangeland or wetland restoration, the application of biochar to soil, and the establishment of permanent plantings.

Projects that result in the clearing of native forest are not permitted. Projects must relate to activities that generate a minimum of 2,000 t $\mathrm{CO}_{2}$ eq. a year on average. ${ }^{80}$ Smaller projects, therefore, must seek collaboration in order to form aggregated projects. ${ }^{81}$ Projects can be Kyoto or non-Kyoto projects, or both (in the last case, eligible and non-eligible offsets remain distinguishable). ${ }^{82}$

\subsubsection{Methodology Determinations}

Projects are only eligible when covered by an approved methodology. Depending on the methodology, all kinds of conditions must be met to ensure that emission reductions are real and additional. Conditions are also set on reporting and auditing. An Emissions Reduction Assurance Committee (ERAC) has been set up to ensure the application of integrity standards. ${ }^{83}$ According to these standards,

79 'Projects that remove carbon dioxide from the atmosphere by sequestering carbon in living biomass, dead organic matter or soil, and/or projects that avoid emissions of greenhouse gasses from these three source': s. 54 .

8o CFi Rule, s. 66.

81 The Emissions Reduction Fund White Paper suggests that this minimum can be changed later: Australian Government, 'Emissions Reduction Fund White Paper' (Canberra: Commonwealth of Australia, 2014), at 45 .

82 CFI Act, s. 11.

83 CFI Act, s. 254; formerly known as Domestic Offsets Integrity Committee. 
- abatement is permanent and additional to business as usual ('additionality test');

- is measurable and verifiable;

- takes into account possible leakage (which must be deducted from the abatement);

- meets internationally recognized accounting standards;

- is supported by relevant (peer reviewed) science;

- accounts for cyclical variability. ${ }^{84}$

A proponent of a project may apply for methodology approval, or ERAC may approve a methodology of its own accord. A methodology can be projectspecific, but ideally it should have applications beyond the particular proposed project. A methodology sets the rules on how to calculate emission reductions in the project, how to determine the baseline, and how to report, keep records, and monitor. Once endorsed by ERAC, the relevant federal government minister confirms the methodology.

Methodologies are regularly updated. For the agricultural sector, the following methodologies had been established as of June 2016:85

- Beef cattle herd management;

- Destruction of methane from piggeries using engineered biodigesters;

- Destruction of methane generated from dairy manure in covered anaerobic ponds;

- Destruction of methane generated from manure in piggeries;

- Estimating sequestration of carbon in soil using default values;

- Fertilizer use-efficiency in irrigated cotton;

- Reducing greenhouse gas emissions in beef cattle through feeding nitratecontaining supplements;

- Reducing greenhouse gas emissions in milking cows through feeding dietary additives;

- Sequestering carbon in soils in grazing systems.

To get a sense of the requirements imposed on participating farmers by these methodologies, I will consider two examples, one emission-avoidance method and one sequestration method.

\footnotetext{
84 CFI Act, s. 133 .

85 Several other methodology determinations were revoked in 2015 following the start of the ERF, while others were amended. For an up-to-date overview of all methods, see $<w w w$ .environment.gov.au/climate-change/emissions-reduction-fund/methods>.
} 
Projects aimed at methane destruction in piggeries involve installation and use of engineered biodigesters to treat manure, receiving the manure in the biodigesters (instead of an uncovered anaerobic lagoon) to undergo anaerobic decomposition, as well as installation of a flaring system that monitors performance. ${ }^{86}$ Under this project type, it is permitted to add additional waste to the biodigester, under strict conditions (limiting both the type and amount of waste added to the manure). The methodology lays down a wide range of detailed rules and conditions. It includes data-collection requirements, e.g. the quantity of biogas sent to a combustion device. Project owners are obliged to use a prescribed model to help them estimate the net abatement amount. ${ }^{87}$ There are rules on how to calculate the baseline, the emissions associated with the project (e.g. emissions caused from additional energy use, which must be deducted from the avoided methane emissions), the net greenhouse gas abatement, and the net emissions avoided. The methodology also has extensive rules on monitoring, record keeping, and auditing. It lists all the matters that need to be monitored (twenty-three in this example), prescribing the parameters and units, as well as the measurement procedure and measurement frequency. It also lists forty-eight types of documentation that must be kept by the farmer. These include a Quality Assurance Plan (detailing how the optimum performance of the equipment will be maintained for the duration of the project), operation logs for the gas-capture system, piggery-feed usage data and diet analysis, gas-flow meter information, and the methods used for handling the digestate.

Another methodology is for sequestering carbon in soils in grazing systems. ${ }^{88}$ These projects encompass a variety of measures aimed at improving carbon storage in soils. Soil carbon can be stored in grazing systems by increasing the amount of organic matter in agricultural soils, for instance by converting from continuous cropping to permanent pasture, undertaking pasture cropping, managing pasture through pasture irrigation, applying organic or synthetic fertilizer to pastures (under certain conditions), or rejuvenating pastures, including through seeding (including reducing nitrous-oxide emissions

86 Carbon Credits (Carbon Farming Initiative) (Destruction of Methane from Piggeries using Engineered Biodigesters) Methodology Determination 2013, <www.comlaw.gov.au/ Details/F2015Coo572>.

87 The so-called 'PigBal' model, produced by the Government of Queensland and Australian Pork to calculate nutrient and salt content in the waste from a piggery.

88 Carbon Credits (Carbon Farming Initiative) (Sequestering Carbon in Soils in Grazing Systems) Methodology Determination 2014. The complex, 112-page-long document, is available online: <www.comlaw.gov.au/Details/F2015Co0582>. 
from soils through tillage), and by managing grazing through changing stocking rates, or altering the timing, duration, and intensity of grazing. Farmers can select the measures they want to implement, but must adopt at least one new management activity. The land that is used for soil-carbon storage must be delineated in accordance with the CFI Mapping Guidelines, ${ }^{89}$ and must consist of land that was under permanent pasture, or was continuously cropped, over the five years prior to the start of the project. The methodology determination is concerned with measuring soil carbon, which is done through the sampling of soils by a qualified person, namely a technician with qualifications from a nationally accredited course or recognized by a nationally accredited institution, with competencies prescribed in the CFI Soil Sampling and Analysis Method and Guidelines. ${ }^{90}$ The methodology sets detailed rules on sample collection and on the analysis of the samples. Sampling starts with baseline sampling, followed by sampling at regular intervals, and must take place at a depth of at least 30 centimeters. The methodology has rules on how to calculate the baseline carbon stock, the project carbon stock, and the project emissions, so as to calculate the net abatement amount. The calculations cover the amount of organic carbon in the soil, emissions of methane and nitrous oxide from livestock, emissions of nitrous oxide and $\mathrm{CO}_{2}$ from synthetic fertilizer, emissions of $\mathrm{CO}_{2}$ from lime, and emissions of nitrous oxide, methane, and $\mathrm{CO}_{2}$ from tillage.

Sequestration projects can have a 25-year or 100-year permanence period. ${ }^{91}$ There are extensive rules on carbon maintenance. ${ }^{92} \mathrm{~A}$ 'carbon maintenance obligation' is imposed upon the sequestration project proponent to avoid a situation where sequestered carbon is emitted after the credits have been issued. According to the obligation, it is not permitted to carry out activities on lands used for sequestration which result (or are likely to result) in a reduction below the benchmark sequestration level of the sequestration of carbon in the relevant carbon pool in the area. ${ }^{93}$ The requirement must be registered in the

89 Carbon Farming Initiative (CFI) Mapping Guidelines 2015, <www.environment.gov.au/ climate-change/emissions-reduction-fund/cfi/publications/cfi-mapping-guidelines $-2015>$.

90 CFI Soil Sampling and Analysis Method and Guidelines 2014, <www.environment.gov.au/ climate-change/emissions-reduction-fund/methods/sequestering-carbon-in-soils $>$.

91 CFI Act, s. 86A.

92 See, extensively, Pamela O'Connor, Sharon Christensen, W.D. Duncan, and Angela Phillips, 'From Rights to Responsibilities: Reconceptualising Carbon Sequestration Rights in Australia', 30(5) Environmental and Planning Law Journal 403 (2013). 
land title register. ${ }^{94}$ Only 'permitted carbon activities' may occur on lands used for sequestration. If a reduction below the benchmark sequestration level occurs, the owner or occupier of the land must take all reasonable steps to ensure that the benchmark level is restored..$^{95}$ Monitoring requirements apply to monitoring the risk of reversal events and known erosion events in the project area, especially when a portion of the project area is subject to bare fallow, or suffers a fire or other event that reduces surface vegetation cover to below 40 per cent, or when it is converted from permanent pasture to cropland with no pasture cover. Once again, the methodology lists extensive documentation that must be kept by the farmer, as well as reporting requirements.

\subsubsection{Issuing ACcUs}

The second step, after a methodology has been approved, is the formal recognition of the project entity. It used to be that the project proponent had to apply to the Clean Energy Regulator for recognition under the scheme. The CER would grant recognition where the proponent was a 'fit and proper' person, not insolvent, etc. This step, however, was dropped with the conversion to the ERF, although the CER still checks that the applicant is a 'fit and proper' person. ${ }^{96}$ The project is compared with the relevant methodology and a check is carried out that the emission reductions are real and additional. Up until 2015, the reporting period began as soon as the project was approved. Since 2015, the proponent of an eligible project must first seek a carbon abatement contract (see next section). After the proponent has secured the funds, the project as well as the reporting obligation commence.

The reporting period is a period of between six months and two-to-five years (two for emission-avoidance projects and five for sequestration projects). Projects have multiple reporting periods. Reports must comply with the requirements of the methodology and usually have to be accompanied by an audit report. ${ }^{97}$ Eligible projects must undergo an initial audit within the first six months of the project, with at least two audits to follow. ${ }^{98}$ The audits must be undertaken by auditors registered under the National Greenhouse and

\footnotetext{
94 CFI Act, s. 40.

95 CFI Act, s. $97(10)$.

96 CFI Act, s. 6o, and the more detailed rules of the CFI Rule, ss. 6o-64, which, for instance, stipulate that the authorities can take into account whether individuals, bodies corporate, or executive officers of bodies corporate committed criminal acts or offenses comprising of dishonest conduct or environmental offenses, both domestically or abroad, as well as 'any other events that the Regulator considers relevant'.

97 CFI Act, s. 76(4).

98 CFI Rule, ss. $72-80$ B.
} 
Energy Reporting Amendment Regulation 2015. ${ }^{99}$ Reports are used by the CER to calculate the number of ACCUs that have been generated by the project us-

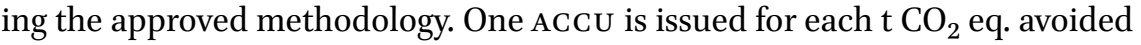
or sequestered. For sequestration projects, generally there is a 5 per cent deduction in ACCUs issued to account for the risk of reversal. ${ }^{100}$

After the end of a reporting period, the CER may issue a certificate of entitlement in respect of the project for the reporting period. ${ }^{101}$ That entitlement leads to the issuing of ACcUs to the applicant's account in the Emissions Reduction Fund Register. ${ }^{102}$ The 'first person' can transfer these units to someone else, within or outside Australia. Extensive rules regulate these transfers, ${ }^{103}$ as well as the Register. ${ }^{104}$ As already stated, since 2015, it is primarily the government that purchases the ACCUs, which it transfers to a special Commonwealth Registry account, in accordance with the Australian National Registry of Emissions Units Act 2011. ${ }^{105}$ The government is required to publish annual reports on its purchases. ${ }^{106}$ Credits can be issued over the course of the entire crediting period for the project, which is seven years for an emission-avoidance project or twenty-five years for a sequestration project, although different crediting periods may be set. ${ }^{107} \mathrm{~A}$ project may have up to two crediting periods.

There are a number of situations in which already-generated ACcus must be handed back to the regulator. This may be necessary, for example, when there has been a reversal of sequestration or when it becomes evident that ACCUs were issued on the basis of incorrect information. ${ }^{108}$ Farmers do not have to hand back ACCUs where carbon stocks are lost because of bushfire, drought, or pest attack, as long as they take reasonable steps to reduce the risk of such events and re-establish the carbon stores. ${ }^{109}$

\subsubsection{Auctions and Carbon-Abatement Contracts}

As of July 2015, with the start of the ERF, a new phase was added to the process, in which the CER, on behalf of the government, purchases ACCUs through a

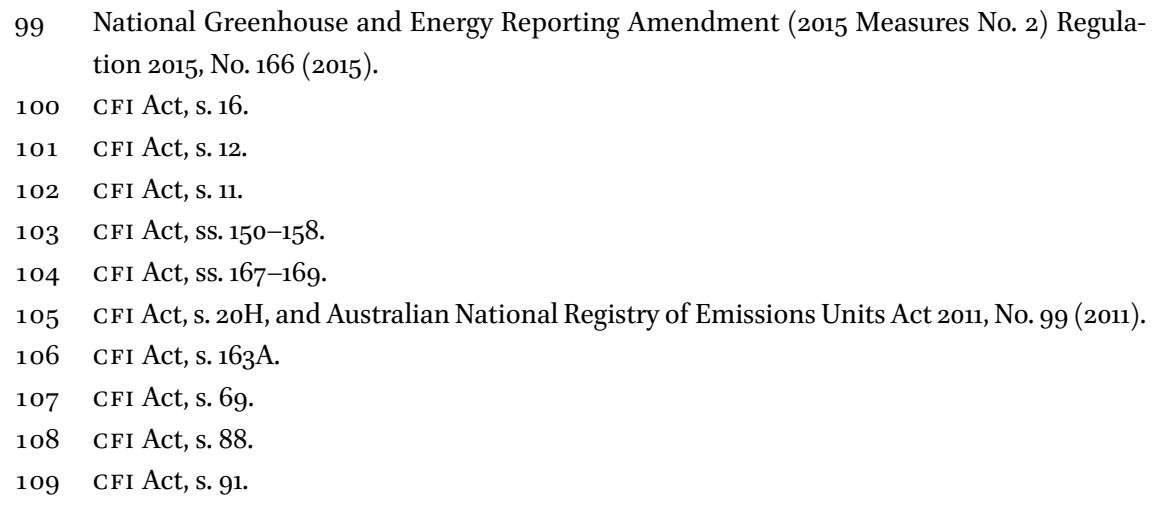


contract with the farmer. The CER can enter into fixed-price carbon-abatement contracts with proponents of eligible projects only. It may do so whether or not any ACCUs have been created at that point in time. There is thus a timing mismatch. ${ }^{110}$ Usually, a proponent will want to ensure that initial investments pay off, and will therefore seek a carbon-abatement contract before the project begins. Once such a contract has been secured, the proponent can seek funding for the project and secure a forward-investment contract. The total duration of a contract may not be longer than ten years. ${ }^{111}$

The CER is free to decide how it purchases carbon abatement. It may do so through reverse auctioning, tendering, or by another method. ${ }^{112}$ The purchasing process, however, must comply with six principles: the maximum amount of carbon abatement must be purchased, against the least cost, free of unreasonable administrative costs, and in a manner that ensures integrity, encourages competition, and provides for the fair treatment of all participants. ${ }^{113}$ So far, purchases have been through reverse auctions, in which a project proponent bids a price for the carbon abatement expected from the project. ${ }^{114}$ The winning bids, i.e. those that achieve the largest amount of abatement at lowest cost, are contracted. ${ }^{115}$ Regular contract law applies. ${ }^{116}$ However, regular government procurement law and public-governance and accountability law do not apply. ${ }^{117}$ Carbon-abatement contracts must be registered in the ERF Register. ${ }^{118}$

110 Macintosh, supra note 76, at 191; and Climate Change Authority, Carbon Farming Initiative Review (Canberra: Commonwealth of Australia, 2014), at 33. These costs, on the other hand, are deductible under tax law: Celeste Black and Michael Dirkis, 'Farming Carbon: Taxation Implications of the Carbon Farming Initiative', 21(1) Revenue Law Journal 1 (2012), at 13-14.

111 CFI Rule, s. 10.

112 CFI Act, s. 2oF.

113 CFI Act, s. 20G(3).

114 Auctions took place in April 2015, November 2015, and April 2016. The next auction was planned for November or December 2016. For auction results, see $<$ www.cleanenergyregu lator.gov.au/ERF/Auctions-results $>$.

115 A model carbon abatement contract is available online through $<$ www.cleanenergyregula tor.gov.au/ERF/Want-to-participate-in-the-Emissions-Reduction-Fund/Step-2-Contracts -and-auctions $>$.

116 CFI Act, s. 20K.

117 CFI Act, s. 2oJ determines that neither the Public Governance, Performance and Accountability Act 2013 nor the Commonwealth Procurement Rules under the Financial Management and Accountability Regulations 1997 apply.

118 CFI Act, s. 168(5). 


\subsubsection{Compliance}

The CER is responsible for the enforcement of the scheme. It monitors compliance, not only by checking the information at its disposal (project information, audited reports, etc.), but also by conducting audits itself ${ }^{119}$ or undertaking site inspections. ${ }^{120}$ The CER can impose a range of administrative sanctions, such as requiring the relinquishment of a specified number of ACCUs (when issued on the basis of false or misleading information, or when a sequestration project ends before the end of the permanence period), ${ }^{121}$ accepting so-called 'enforceable undertakings' from a regulated entity (i.e. written, publicly accessible, statements by a person or organization that they will do certain things to improve compliance with the legislation, which may, if breached, result in court action), ${ }^{122}$ or issuing infringement notices. The CER can also take legal action for breaches of civil-penalty provisions; in such a case, pecuniary damages are sought through the court, for instance when the project proponent infringes carbon-maintenance obligations. Criminal sanctions, including imprisonment, may also apply. ${ }^{123}$ If a person is convicted of an offence relating to fraudulent conduct, and the issuance of ACCUs is attributable to the commission of the offence, the court may order relinquishment of ACCUs. ${ }^{124}$

\subsubsection{Adding a Cap: The 'Safeguard Mechanism'}

On 1 July 2016, the so-called 'safeguard mechanism' took effect. This is laid down in the (amended) National Greenhouse and Energy Reporting Act 2007 and related regulations. ${ }^{125}$ It sets a cap on the emissions of Australia's major (>100,00o t $\mathrm{CO}_{2}$ eq./year) GHG-emitting industrial and electricity facilities, which together cover roughly half of Australia's emissions. This is seen as an important supplement to the ERF, for without the cap, a decrease in emissions through projects funded by the ERF could be accompanied by an increase elsewhere, thus rendering the ERF ineffective. Because facilities can comply with the cap (called a 'baseline') by purchasing ACcus (from farmers, for example) to offset their emissions, ${ }^{126}$ the safeguard mechanism may be expected

\footnotetext{
119 CFI Act, ss. 213-215.

120 CFI Act, ss. $194-208$.

121 CFI Act, ss. 88-91.

122 CFI Act, s. 237.

123 Either under provisions on fraudulent conduct or false and misleading statements of the Criminal Code 1995, or under CFI Act, ss. 234-235.

124 CFI Act, s. 171.

125 National Greenhouse and Energy Reporting Act 2007, No. 175 (2007), as amended through the Carbon Farming Initiative Amendment Act 2014, No. 119 (2014).

126 National Greenhouse and Energy Reporting Act 2007, s. 22XF.
} 
to lead to an increase in private purchases of ACCUs from non-ERF-funded CFI projects. $^{127}$

\section{Experiences with the CFI Act}

Having described the regulatory design of the Australian scheme, we may now turn to its implementation, in order to understand both stakeholder experience and the scheme's pros and cons. I report on the findings of my empirical research. First, I explain the methodology used. I then present information on the number and kinds of projects run by farmers under the CFI Act. The largest part of this section outlines stakeholders' views on the impact of the CFI Act. I focus on the motivation of farmers to participate in the CFI/ERF, the role of consultants, the impact of the change from a market-based to a governmentfunded scheme, the 'financing gap', administration and compliance, the scope of the scheme and its methodologies, the results of the scheme for the environment as well as for individual farmers, and the way forward.

\subsection{Methodology}

The empirical part of the research consisted of a brief case-study phase and a longer interview phase. Case studies of selected CFI/ERF projects were conducted for a better understanding of the kinds of project that are run on farms and to gather background information for the interviews. All of the 630 projects on the ERF Register as at 1 May 2016 were assessed using pre-determined selection criteria. ${ }^{128}$ Seven cases were selected: two cases of methane capture in piggeries, two cases of sequestration of grazing land, one case of reforestation, and two avoided-deforestation cases. Information for the case studies was primarily gathered through publicly available sources, such as government and news websites.

The bulk of the empirical data was generated in interviews with highlevel stakeholders, i.e. representative associations for the farming industry,

127 The first surrender of ACCUs to avoid the excess-emissions situation is due on 28 February 2018; see <www.cleanenergyregulator.gov.au/NGER/The-safeguard-mechanism/ Key-dates $>$.

128 E.g. the projects should be representative for the other parts of the world and they should entail different types of farm and different mitigation actions; ideally, the projects should also entail some adaptation actions, should be representative for their kind, and should be in several jurisdictions so as to find possible differences in implementation across jurisdictions. 
consultancy firms that help farmers apply for and run CFI/ERF projects ('carbon agents'), financial and accountancy firms actively involved with the CFI/ERF, and government officials working with the regulatory framework. For each of these four stakeholder categories, at least two or three interviews were held, sometimes involving more than one person employed (or formerly employed) by the stakeholder organization. These persons were in leadership roles (CEOs, directors, etc.) or sometimes had specialized roles (e.g. sustainability or natural-resources managers). Given the law-and-policy focus of my research, they were the most qualified persons within each organization to interview. ${ }^{129}$ (Some information on the functioning of the CFI/ERF, particularly its past functioning, was also obtained from the Australian Climate Change Authority's 2014 review of the CFI. ${ }^{130}$ ) The validity of the interview findings was tested in one stakeholder seminar, two academic seminars, and in two additional interviews: one with senior representatives of the carbon-consultancy sector and another with a major climate change NGO. ${ }^{131}$

\subsection{Introduction: Data on, and Examples of, Carbon-Farming Projects 4.2.1 Number of On-Farm CFI/ERF Projects}

When the carbon-farming scheme took off, farmers were reluctant to participate. The majority of methodology determinations were for activities in the forest and waste sectors. ${ }^{132}$ As of December 2014, there were 178 C FI projects, ${ }^{133}$ only 4 per cent of which were agricultural projects. ${ }^{134}$ Just one per cent of ACC Us were issued to agricultural projects. ${ }^{135}$ By that point the CFI had caused

129 Interviews were conducted in April and May 2016. Due to EU research-ethics requirements, this article does not refer to the names of the persons interviewed. Interview reports for each interview are on file with the author. Anonymized interview reports are stored in the Tilburg University data storage facility.

130 Climate Change Authority, supra note 108.

131 The seminars took place in May and July 2016; the validation interviews in August 2016.

132 Climate Change Authority, supra note 110, at 17.

133 Ibid., at 19.

134 Forty-six per cent were landfill and waste-treatment projects, $19 \%$ were avoideddeforestation projects, $19 \%$ were other types of forest projects, and $13 \%$ were savannaburning projects; ibid., at 19 .

135 Sixty-one per cent of credits have been for landfill and waste-treatment projects, $29 \%$ for avoided-deforestation projects, $5 \%$ for reforestation and other forestry projects (these are likely to generate increasing amounts of credits over time because forest growth generally accelerates five to ten years after planting), and $4 \%$ for savanna-burning projects; ibid., at 20. 
a 2-per-cent reduction in emissions covered by the CFI. ${ }^{136}$ All credits for agricultural projects were issued to projects that destroyed methane generated from manure in piggeries. ${ }^{137}$ According to the Climate Change Authority's review, poor participation by the agricultural sector was almost entirely attributed to policy uncertainty, i.e. uncertainty about the future of the heavily debated Australian ETS and the potential impact on the carbon price of the envisaged linkage with the EU ETS. ${ }^{138}$ Other reasons included: lack of methodologies; difficulty of compliance with methodologies; limited access to capital; lack of economies of scale on many farms; and difficulty of access to information about emission-reduction projects. ${ }^{139}$ These challenges were exacerbated by the existence of many small and dispersed participants in the sector (55 per cent of Australia's farm businesses report operations valued at less than $\mathrm{AU} \$ 100,000 / \mathrm{US} \$ 76,500) . .^{140}$

The situation changed once emission trading was dispensed with and the ERF became operational. The first auction took place in April 2015, i.e. before the actual launch of the ERF. It was accessible only to those sectors covered by the original CFI scheme. About half of the proposed emission reductions $\left(28 \mathrm{Mt} \mathrm{CO}_{2}\right.$ eq.) came from farm projects-mainly avoided deforestation and soil-sequestration projects. While the agricultural sector feared that it would soon come to be outbid by larger players, such as energy producers and large industry, ${ }^{141}$ the second auction, which was the first one under the ERF, proved that fear unjustified. The lion's share of carbon-abatement contracts went to farmers and landowners for agricultural, forestry, and land-use projects. ${ }^{142}$

136 As at 3 December 2014, 10.6 million credits had been issued. This is about $2.5 \mathrm{~m} \mathrm{t} \mathrm{CO}_{2}$ eq. per year.

137 Ibid., at 30.

138 Ibid., at 32 . The review is very clear about this: 'Policy uncertainty plays havoc with price expectations, in this case about future prices for credits, because a change in policy settings can change demand. Heightened uncertainty over future prices increases the risks around expected revenue streams from a project, deterring some potential participants from taking up a project.'

139 Climate Change Authority, supra note 9, at 304.

140 Ibid.

141 Sarina Locke, 'Farms Could be Shut out of Next Emission Reduction Fund Auction Given Big Corporates will be Competing', ABC Rural News, 27 April 2015, <www.abc.net.au/ news/2015-04-27/carbon-farming-auction-good-start-to-reducing-emissions/6418792>.

142 Sarina Locke, 'Landholders the Biggest Winners in \$550 Million Carbon Abatement Auction', ABC Rural New (13 November 2015), <www.abc.net.au/news/2015-11-12/landholders -biggest-winners-in-carbon-abatement-auction/6935968>. Details of the auction results are available on the CER's website <www.cleanenergyregulator.gov.au/ERF/Auctions -results>. 
According to news reports, 'big industry, which was expected to take up more of this round of funding, was late with its projects.' ${ }^{43}$ About 9 per cent of abatement in the second auction was for agricultural projects (excluding vegetation). ${ }^{144}$ Thus, under the $\mathrm{ERF}$, the agricultural sector began to increase its share of carbon abatement in non-vegetation projects as well, compared to the situation under the CFI. The third auction took place in April 2016 and saw a further increase in the share of farmers and landowners. ${ }^{145}$ In the course of three auctions, a total of 309 carbon-abatement contracts have been awarded, to deliver more than $143 \mathrm{Mt} \mathrm{CO}_{2}$ eq. of abatement. ${ }^{146}$

As noted above, 630 projects had been registered in the ERF Register as at 1 May 2016. ${ }^{147}$ This represents a dramatic increase from December 2014, when only 178 projects had been registered.

It is important to reiterate that farmers have frequently been involved in projects listed in categories other than agriculture, especially vegetation and savanna burning (these being fire-management measures to reduce the risk of wildfires). It is estimated that the majority of the vegetation and

TABLE $1 \quad$ Number of ERF-registered projects, per sector, as at 1 May 2016.

\begin{tabular}{lr}
\hline Vegetation & 350 \\
Waste & 124 \\
Savanna burning & 70 \\
Energy efficiency & 36 \\
Agriculture, consisting of: & 32 \\
- sequestration grazing lands (17) & \\
- methane capture/biogas piggeries (12) & \\
- beef cattle herd management (3) & 10 \\
Industrial fugitives & 8 \\
Transport & 630 \\
Total &
\end{tabular}

143 Ibid. Industrial projects received $12 \%$ of all funding (AU $\$ 69 m)$.

144 As is shown at the CER's 's website, <www.cleanenergyregulator.gov.au/ERF/Auctions -results/November-2015>.

145 According to the CER's website, $<$ www.cleanenergyregulator.gov.au/ERF/Auctions-results/ april-2016>.

146 Ibid.

147 See <www.cleanenergyregulator.gov.au/ERF/project-and-contracts-registers/project-reg ister $>$. 
savanna-burning projects, which achieve an abatement of 98.5 and $8 \mathrm{Mt}$ $\mathrm{CO}_{2}$ eq., respectively, occur on farmland, with the revenue going to farming businesses. ${ }^{148}$

\subsubsection{Illustrative CFI/ERF Projects Run by Farmers}

To get a better idea of the kind of on-farm project that has been successful under the ERF, a few case-study examples will be discussed here.

\subsubsection{Methane Capture in Piggeries}

An intensive pig farm in Victoria, with 12,000 pigs, on 2,000 acres, and fifteen staff, received a carbon-abatement contract in April 2015 for the capture of biogas generated from the decomposition of manure in biodigester-style anaerobic lagoons and the combustion of the methane component of the biogas. The owner of the piggery sees himself as an innovator. Since the early 1980 , he has been introducing new technologies and spends approximately AU $\$ 300,000$ (US $\$ 229,630$ ) per year on capital works, including farm improvements, to improve production to meet health-and-safety and environmental standards. ${ }^{149}$ The farm is highly automated and uses written procedures for its staff. It has received Quality Assurance Accreditation, a voluntary certification scheme by Australia Pork, which focuses on animal welfare and food safety. The sector is well aware of the negative environmental impacts of pig farming. The main issues are the odour and dealing with large quantities of effluent. ${ }^{150}$ Reducing odour was achieved by modifying the design of the sheds. Manure effluent was dealt with by installing technologies to capture methane from the waste and convert it into biogas and re-use the waste digestate as organic fertilizer. It is the latter project that was contracted under the ERF. The result of the project is that methane emissions are reduced (the effluent treatment-and-recycling system at the farm has resulted in an 81-per-cent reduction in emissions at the site), ${ }^{151}$ renewable energy is generated, displacing fossil fuels used for heating and power generation, and a significant reduction

148 Interview with Clean Energy Regulator representatives, 10 May 2016.

149 Lyndal Thorburn and John Langdale, Embracing Change. Case Studies on How Australian Firms Use Incremental Innovation to Support Growth (Sydney, Australia: Macquarie University 2003), at 97 .

150 Ibid., at 98 .

151 Alex Sampson, 'Piggery and Compost Company up for Premier's Sustainability Awards', Weekly Times, 30 September 2014, <www.weeklytimesnow.com.au/agribusiness/piggery -and-compost-company-up-for-premiers-sustainability-awards/news-story/7ob5 b7eef39 4b48119fd4d93cf6adb8o>. 
in odour has been achieved. ${ }^{152}$ The total number of ACCUs issued for 2014/2015 and 2015/2016 was 18,590 (9,29o t $\mathrm{CO}_{2}$ eq. per annum).

\subsubsection{Sequestration in Grazing Land}

An organic cattle farm in Queensland registered a project in October 2015 aimed at removing $\mathrm{CO}_{2}$ from the atmosphere by sequestering carbon in its soil-grazing system. The farm uses a targeted method of rotational grazing, moving cattle to paddocks as soon as the grass stops growing, allowing the cattle to graze and start the growth process again, thus accelerating the increase of carbon uptake. ${ }^{153}$ This particular farmer was involved in developing the methodology in association with Central Queensland University; ${ }^{154}$ he is also the chairman of Healthy Soils Inc. Landcare, an organization that 'conducts research on farm trials and other methodologies to assist landholders, farmers and graziers to improve long term viability meanwhile reducing their reliance on chemicals; thus, reducing soil degradation and erosion.155

Another example of the same method is a sequestration project in New South Wales, also registered in October 2015. It is part of a bigger on-farm innovation project which began in 2002; it includes the construction of weirs and swales to slow water flow. ${ }^{156}$ This has increased soil moisture and vegetation growth. Targeted grazing has increased soil organic matter and encouraged regeneration of native grasses. Both grazing and the number of livestock present fluctuate with the carrying capacity of the area. In addition to the mitigation achieved, the project has led to notable co-benefits, such as a 250-per-cent increase in stock-carrying capacity, a 15-to-23-per-cent profit margin on cattle production, a constant river outflow regardless of inflow, improved landscape hydrology, and increased native biodiversity. 157

As at June 2016, these two projects, while registered, had not yet received a contract.

$15^{2}$ Australian Pork, 'Aussie Pork Industry Takes the Lead for a Cleaner Environment' (Media Release 3 May 2015).

153 Rachel Conaghan, 'Soil Test Breaks Vital Ground', Rural Weekly, 27 March 2015, <www .ruralweekly.com.au/news/soil-test-breaks-vital-ground/2585983/>.

154 Ibid.; CQUni, 'CQUni Researchers Involved in Healthy Soils Field' (Media Release, 22 July 2014).

155 See the Healthy Soils Inc. website, <www.healthysoils.org.au >.

${ }_{15} 6$ Soils for Life, Case study. Innovations for Regenerative Landscape Management Project (Fairbairn, Australia: Outcomes Australia, 2012), at 128-35.

157 Ibid. With such co-benefits, questions arise as to the role of the ERF. (Is the ERF the real push factor for the changes in agricultural practices? What is the additionality? What is the role of public funding?). These questions will be discussed in the next section, below. 


\subsubsection{Reforestation by Mallee Plantings}

Typical for the south of Western Australia are reforestation projects involving the planting and management of mallee trees (a vegetation group that occurs in semi-arid areas of southern Australia) on agricultural land, both to store carbon and to stop degradation and salinization of farmland. It is a good example of a measure that achieves both mitigation and adaptation simultaneously. The mallee oil, harvested from the trees, can be sold as a biofuel. To date, a lack of investment in oil production and in mallee-oil-powered biomass generators is preventing large-scale biofuel production from mallee. ${ }^{158}$ These Western Australia reforestation projects have a 25 -year permanence period. They were registered as eligible projects under the ERF in April 2015 by a Sydney-based carbon agent on behalf of the farmers in Western Australia. One project was granted a carbon-abatement contract by the CER under the ERF in April 2015. No ACCUs had been issued as at June 2016.

\subsubsection{Avoided Deforestation}

A project in New South Wales under the avoided-deforestation methodology involves the protection of 8,500 hectares of native forest through the prevention of harvesting activities (clearing and clear-felling). Prior to the project, the farmer had received a permit to clear trees for grazing land. Under the project, he manages the forest for protection over a 100-year period (until 6 June 2114). Management includes installing fire breaks around the forest to prevent bushfire damage. The project was jointly developed by two carbon agents and leads to an additional revenue stream for the farmer, which is especially important considering that his property is located in a drought-prone area. ${ }^{159} \mathrm{~A}$ contract was awarded under the ERF in April 2015, with a total of 238,828 ACCUs issued.

A similar case under the avoided-deforestation method involves the protection of 7,00o hectares of dry native forest on farmland as part of a bigger onfarm project to 'drought-proof' the land. This project was contracted in April 2015 and received 252,681 ACCUs. The money raised from the ERF was used by the farmer to buy another property and put on new workers. ${ }^{160} \mathrm{~A}$ carbon agent

\footnotetext{
158 Sean Murphy, 'Mallee Oil', ABC TV Broadcast, 22 June 2014, <www.abc.net.au/landline/ content/2014/s4030485.htm>.

159 Anonymous, 'Forest Project Gets Approval', Narromine News Online, 29 January 2014, $<$ www.narrominenewsonline.com.au/story/2053451/forest-project-gets-approval/>.

160 Tom Arup, 'Wide, Brown Land Becomes a Home to Carbon Farming', Sydney Morning Herald, 17 August 2014, <www.smh.com.au/national/wide-brown-land-becomes-a-home-to -carbon-farming-20140816-104tov.html>.
} 
assists the farmer with the administrative work; in return, the agent takes a portion of the carbon credits. ${ }^{161}$

\subsection{Stakeholders' Experiences with Carbon Farming in Australia}

\subsubsection{Farmers' Motivation to Run Projects under the CFI/ERF}

\subsubsection{Slow Start, Growing Interest, and Attitude Change}

In the course of the interviews, all respondents agreed that the CFI, and especially the ERF, has changed and is still changing the attitudes of farmers towards climate-smart agriculture. Carbon agents and representatives of farmers' organizations and financial institutions all stressed that the farming sector is, generally, very conservative. Farmers tend to stick to traditional work methods and have a negative attitude towards environmental and climate policies, as these may interfere with their preferred agricultural practices. 'Farmers felt that carbon was a bad thing that would only cost them money.' It took years of convincing by the government and by project developers to get farmers interested. In the early years, the CFI was promoted by carbon agents or 'aggregators'. The agents developed methodologies, lobbied the government to get them recognized, developed projects, and called on farmers to persuade them to implement them. The farmers' organizations were quite reluctant to be engaged, with the exception of Australia Pork. (This lobby group for the piggery industry developed a methodology, had it accepted by the government, and persuaded its members to use it. Thus, in the pork sector, the sector's organization played the role of carbon agents in other sectors.) In the beginning, it was mainly farmers with a pre-existing interest in improving environmental performance who became engaged in the national scheme - as well as big farms approached by aggregators. According to a representative of a major farmers' organization, those in the latter category were often farmers in desperate economic circumstances in areas struck by drought, such as in western New South Wales. They needed cash; for some of them, the prospect of twenty-five years of income from the national scheme was the only option left.

Now, after several years of experience with the CFI/ERF, farmers are increasingly realizing that they can make money from carbon projects. A carbon agent said that a familiar, somewhat ironic, phrase among farming consultants is that 'you can get an idea in a farmer's head only through a cheque book'. It is generally felt that the price certainty offered by the ERF has had the biggest influence on farmers' participation rates. As indicated above, the data indeed show a large jump in the number of registered projects after the introduction of the ERF, a jump that surprised many (see Section 4.3.3, below). Carbon agents have

161 Ibid. 
noticed that farmers have begun to approach them-instead of the other way around. It should also be emphasized, though, that the vast majority of farmers are currently not engaged in ERF projects.

\subsubsection{An Aging Sector}

Most respondents referred to the fact that those working in the agricultural sector in Australia are aging. Several respondents pointed out that farmers on average are in their late fifties and almost all farms are family businesses. ${ }^{162}$ The sector is facing a transition to a younger generation. Often, there are no children who want to take over a farm, in which case farmers must find a buyer. As a consequence, many farmers are only interested in securing sufficient income for the next decade or so, and do not look beyond. The additional income from the ERF allows these farmers to have a smoother generational transition. The CFI/ERF assists in the diversification of agricultural practices and in succession planning. It allows, for instance, a farmer to buy land from a neighbouring aging farmer using funds generated from CFI/ERF vegetation projects on the newly acquired land.

It was also generally felt that the older generation of farmers is much more reluctant to move towards sustainable or climate-smart farming than the younger generation. This indicates that there should be a growth in potential for climate-smart agriculture after the transition to the next generation.

Banks are aware of the problem of aging and are looking for financial solutions to achieve a smooth transition to younger farmers. Integration of farms is financially challenging, as it leads to larger farms and a larger financial burden on young farmers. The new generation often also has to buy out siblings who do not want to be involved in farming. One respondent indicated that his bank is in the process of developing a financial product that helps a young farmer to buy land from an older farmer by offering him or her a longer period of financing. The bank would remain involved for five years, as would the older farmer. In this way, the bank offers the younger farmer long-term financial security, while the older farmer stays engaged with the land (which is deemed important from a social perspective).

162 Data on the number of family-owned farms are consistent; see National Farmers' Federation, NFF Farm Facts: 2012 (Kingston, Australia: National Farmers' Federation, 2012), at 5-6, as well as the Nexus Commonwealth of Nations Network website on agriculture in Australia, <www.commonwealthofnations.org/sectors-australia/business/agriculture/>. The average age is more difficult to establish; see ibid., at 6 (52 years), and Victorian Farmers Federation, 'Inquiry into the Capacity of the Farming Sector to Attract and Retain Young Farmers and Respond to an Ageing Workforce' (Melbourne, Australia: Victorian Farmers Federation, 2011), at 3 (between 53 and 59). 


\subsubsection{Small Farms}

In the early years of the CFI, only large farms were targeted by the carbon agents. Respondents mentioned several reasons for this. At the start, there was a lot of uncertainty about whether the CFI would work and be economically viable for farmers. Also, there were implementation issues. The high level of complexity implied an involvement of large farms, which could carry risks and deal with the complexity more easily. Soil-carbon measures, for example, need to be implemented for three years before one can claim ACCUs. This requires an upfront investment that small farms cannot easily make. The transaction costs are considered high, and legal issues connected to the CFI/ERF can be difficult (due not only to the complexity of the scheme but also to other legal issues, such as the existence of 'native title' in agricultural property, i.e. aboriginal land-use rights). Another important reason for the targeting of primarily large farms in the early years was the fact that larger volumes of abatement could be achieved on them, which is more profitable for consultants.

How to involve the majority of farms in Australia, which are relatively small family businesses? ${ }^{163}$ Carbon agents can aggregate small-farm projects into one large project. With the introduction of the ERF, aggregation has been the government's specific policy. ${ }^{164}$ CER respondents indicated that this has been a successful policy change. A handful of large aggregators are very active under the ERF, especially with vegetation projects. Sometimes landowners are the project proponents, assisted by the aggregators; in other cases, the aggregators themselves are the proponents. This decreases the administrative burden and fixed costs for smaller farms. However, some respondents, both agribusiness representatives and carbon agents, said that it is much more difficult to manage an aggregated project, because one must make sure that all farmers involved comply with the rules. If one farmer does not comply, the whole project is jeopardized. Partly in order to avoid this risk, smaller farms are now becoming involved individually as well. Since there is presently more expertise than there was, and processes have become more automated, there are fewer overhead costs and risks. Moreover, better methodologies could increase the level of abatement on smaller farms and thus contribute to their greater participation. ${ }^{165}$

Farmers' organizations' representatives added: 'Aggregation is expensive and the risks usually are not with the aggregators but with the land holders.

\footnotetext{
163 Similarly, Climate Change Authority, supra note 9, at 304.

164 Following the suggestion made by Climate Change Authority, ibid.

165 The Climate Change Authority recommended to simplify methodologies to increase participation by small farms; ibid.
} 
For small farms, the costs of aggregation are too big.' To engage small farms, they suggested a 'whole of farm approach'. If a small farm wants to reduce greenhouse gas emissions, the most effective way, they said, is to introduce a range of emission-reduction measures across the farm. Under the current scheme, however, the farmer must have, e.g., three separate projects using different methods, with all the administration and overheads that go with that. He or she may have to deal with more than one aggregator, which is costly as well. Having a balance of different methodologies on one farm, according to one respondent, is a way to generate more abatement and more income from the ERF. A 'whole of farm approach' also reduces risks: if one method does not work in the long run, the farmer can intensify other methods to achieve the same overall reductions.

\subsubsection{The Role of Consultants}

Besides promoting the scheme from the start, consultants (carbon agents, aggregators) have developed the most successful methodologies. The avoideddeforestation methodology, for instance, was developed by two firms which invested time and money into its development without the certainty that it would be adopted by the government. Ultimately they were successful, and now earn part of their income from avoided-deforestation projects on farmland they supervise. Another firm has been especially active with the malleeoil and soil-carbon methodologies. Thus, carbon agents target certain types of project. They promote 'their' methodology with farmers and largely take over the application, monitoring, reporting, and auditing work from farmers, in exchange for a portion of the ERF or private-carbon-market income. Some even provide upfront finance for the farmer to initiate the project. Carbon agents use different financial arrangements, but overall it seems that around 30 per cent of the funds generated go to the consultants.

While most carbon agents are based in large cities (and then mostly in Sydney), some have rural roots. Some are quite small and outsource most of their work to local consultants in the area where the projects are being set up, while others have a large (30-plus) staff and manage all the work themselves. The more complex legal work, such as drafting contracts in complex situations, including financial contracts with lenders, is often outsourced to legal advisors at law firms or legal consultants.

The only sector in which consultants have not dominated seems to be the piggery sector, with its methane-to-biogas projects. As I noted earlier, it was Australia Pork that led development of this sector's methodology and encouraged its members to implement it and apply for ERF funds. Here, farmers do the monitoring and reporting themselves, without the help of consultants. 
Once the technology is installed, monitoring is easy because it is largely automated. An external auditor tells the farmer what to monitor and provides assistance if needed.

All respondents were positive about the consultants: "They are needed and do a lot of good work.' Respondents from the CER and Department of the Environment stressed the need to have economies of scale: 'Aggregators are needed in order to make a policy scheme work, in order to get individuals to apply. It has always been a government policy to facilitate the creation of such companies so as to aggregate the implementation of policy goals.'

Aggregation works both ways: in the direction of the farmers and in the direction of the competent authority. The authorities deal with a relatively small number of knowledgeable aggregators. In the interviews, government officials acknowledged that the success of the ERF is largely due to the efforts of the carbon agents and their aggregation efforts: 'Without them, participation in the scheme would have been much lower, and abatement would have been tiny.'

Several respondents indicated that there are two ways in which the integrity of the consultants is checked. The carbon agents must have a financial-services license (under corporate law). The CFI Act has a 'fit-and-proper person' test, which allows the CER to assess the integrity of the aggregators when they register a project, and 'to knock them out of the scheme if they breach the law', to quote one of the CER's representatives.

\subsubsection{CFI v. ERF: Carbon Market or Fixed Price}

All stakeholders maintained that the transition from the CFI to the ERF gave an enormous boost to the national scheme. Under the CFI, everyone expected a low price because of policy uncertainty and because offsets for the industry sector were allowed to cover only five per cent of allowances. ${ }^{166}$ Now, under the ERF, farmers receive long-term contracts (mostly for ten years), with a guaranteed income stream. This is considered important by Australian farmers, who often face droughts, floods, and fluctuating markets. It also makes it easier for them to negotiate with banks when they seek funding. The CER emphasized that the government offers farmers commercially fair and balanced contracts. For example, the contracts take bushfire risks into account and do not have the 'termination for convenience' clause that government contracts usually have (which allows successor governments to end contracts concluded by a previous government).

166 This also was one the main conclusions of the Climate Change Authority's review, supra note 110 , at 3 . 
The carbon agents I interviewed considered price certainty to be the main reason for the success of the ERF. 'Farmers want to know what they will get paid. Under the CFI, we could not give them a price guarantee. Now we can. This allows service providers to step in and develop projects.' Another carbon agent said:

Thanks to the ERF this has become commercially viable. A huge increase in the number of projects and the amount of abatement is achieved, much more abatement than ever anticipated. I think the ERF is a huge success. It has pushed the whole process: projects were developed, implemented, monitored, which leads, step by step, to more knowledge, farmers gradually step up mitigation and adaptation measures, the whole sector is learning and changing. We need the land sector for mitigation and adaptation. This is kick-starting that process because it leads to revenue for farmers and service providers.

The repeal of the ETS and the introduction of abatement contracts under the ERF did not put an end to the sale of ACCUs to private-market parties. Private companies such as Santos (an Australian oil-and-gas company) and Qantas, the Australian airline, still buy farm-generated ACCUs for their private offset programmes.

However, some concerns about the ERF persist, especially in relation to the open auction market. It is still feared-even though the fears have not been realized - that farmers cannot compete with big industries and energy producers wielding a lot of capital. A respondent from an agribusiness organization suggested introducing a partitioning of the budget so that a part of it always goes to agricultural projects.

\subsubsection{Funding Project Investments}

The issue of the financing gap was referred to in Section 3.2.2.4: farmers must invest in a project before they can generate emission reductions to sell to the government under the ERF. The CER interviewees indicated that it was a deliberate policy decision to grant payment after the delivery of abatement. The huge increase in the number of registered projects since the start of the ERF indicates, according to the $\mathrm{CER}$, that the financing gap is not a significant issue.

Other respondents saw the financing gap as a limitation for most project types. In the piggeries sector, producers must buy and install methanecapture and biogas-production technologies. It was said that, in the pork sector, small- and medium-size farms, especially, need kick-start funding. As the agricultural sector is not eligible for the government's subsidy scheme to 
promote renewable-energy technology (ARENA), 167 farmers must seek loans from banks-either small (niche) banks, such as the Clean Energy Finance Corporation, ${ }^{168}$ or, more commonly, the farmer's home bank. Sequestration projects also have upfront costs: they impact on farming activity, cost time, and need investment in compost and soil additives, among other things. Only grazing management has no major upfront costs, for such projects usually involve the introduction of a different grazing regime, or destocking, or setting aside of land.

Carbon agents get paid only after the ERF income is received. According to the agents, this is necessary, or the scheme would be unaffordable to farmers. As already indicated, sometimes aggregators finance not only their own upfront costs but also those of the farmers, ahead of the issuance of ACcUs.

An agribusiness organization's representative indicated that there is a strong reluctance among banks to provide approval for sequestration projects. Banks that have mortgages on land turn down sequestration projects because they think it is too risky to have such a long-term commitment to the land. For some methodologies, a trade-off is thought to exist between the carbon enterprise and agricultural productivity. This is undesirable, not just for farmers, but also for those supplying the finance. One bank made the national news when it turned down two financing propositions from farmers who had ERF projects. ${ }^{169}$ It rejected the proposals because of the poor overall financial situation of the applicant farmers. For them, the ERF was the only profitable activity —an escape from a bad business. The bank's respondent said: 'We want to finance strong sustainable businesses, that do CFI/ERF projects to diversify their activities, but that have a good product on the food and fibre market as well.' A respondent for a major agribusiness organization made a similar point: 'for some drought-struck farms, the ERF is the only hope. That, however, is not deemed sustainable.'

${ }_{167}$ The Australian Renewable Energy Agency's (ARENA) subsidy programme is primarily aimed at the energy sector and has as its main aims improving the competitiveness of renewable energy technologies and increasing the supply of renewable energy in Australia; see $<$ http://arena.gov.au/funding/>.

168 The Clean Energy Finance Corporation (CEFC) is a commercial investment organization, created by the Australian government under the Clean Energy Finance Corporation Act 2012. It invests in projects concerning renewable energy, energy efficiency, and low-emission technologies, including in the agricultural sector; see <www.cleanenergyfi nancecorp.com.au/energy-efficiency/agriculture.aspx $>$.

169 See, for instance, Sue Neales, 'Heartache as Carbon Credits Turn to Debt', Weekly Times, 20 May 2014, <www.weeklytimesnow.com.au/news/national/heartache-as-carbon-cre dits-turn-to-debt/story-fnkfnspy-1226923533045>. 
Thus banks do not look upon carbon farming in isolation, but see it as an element in a transition to sustainability. Some have developed a financial product offering favourable financing conditions to farmers who want to change to sustainable agriculture, focusing not only on carbon but on a range of different indicators (waste management, recycling, improved irrigation and soil management, animal welfare, etc.). All respondents mentioned the often substantial co-benefits for farmers who are engaged in carbon-farming projects, such as energy savings, increased water retention, improved soil quality, and reversal of salination or erosion. Often such co-benefits offer an additional incentive for farmers to participate (see Section 4.3.7, below).

\subsubsection{Administration and Compliance \\ 4.3.5.1 Competent Authority's Perspective}

When asked about the integrity of the scheme, the CER interviewees stressed that one should consider the scheme as a whole, from project registration through to auditing and accreditation. They mentioned four phases prior to a project's commencement: project registration; auction qualification; auction registration; and the auction. The CER carries out a risk-based check at the registration phase. The 'fit and proper person' test is an important instrument to ensure integrity: 'Who are we dealing with? What have been this person's activities in the past?'

After the auction, there are again several stages at which integrity is checked. First, in the contract phase, the CER can set 'conditions precedent', for instance that payment is subject to local government planning approval for the project, or subject to securing finance to cover the project. The CER respondents indicated that the CER purchases between half and all of a project's abatement, so there is room for caution: it can decide to only buy only part of the expected abatement when there is doubt about the reliability of the claim. This does not imply - interviewees said - that the CER issues contracts to projects it has doubts about. It simply is not always possible to predict exactly how much abatement will be achieved by an entire project from start to finish, an outcome which is dependent as well on unpredictable variables, such as weather conditions.

Then there is the auditing phase. The CER relies heavily on the audit reports. Under the CFI, an audit was needed for every report/claim for credits. Under the ERF, it was decided to reduce this burden. The current scheme requires a minimum of three audits. According to the CER respondents, this is sufficient to check the integrity of the abatement. Fewer than three audits would not be desirable, they said. All respondents were positive about the role of the auditors and considered that the CER could rely on the audits: 'The auditors 
are good, and they are audited as well. They are sometimes pushed to go into a certain direction, but they depend on their reputation. We do not see any scandals.' According to the CER interviewees, only a few irregularities have been found. Mostly they are caused by genuine mistakes. Non-compliance is expected to remain the exception: 'We are seeing early delivery of abatement instead of non- or late abatement. That is a good sign.' To date, no sanctions have been imposed.

The CER, responsible as it is for the process from registration through to auctioning and monitoring and enforcement, is a relatively small organization. It is able to manage the entire process because the process is streamlined. For example, the CER is able to announce which projects have won contracts only a few days after an auction. It can do so because it looks only at price and abatement. The organization does not assess the overall quality of individual projects at the auctioning phase.

\subsubsection{Farmers' Perspective}

Generally, respondents considered that the monitoring and reporting requirements contained in the various methodologies are too complex to be carried out by farmers themselves. As indicated above, the piggery methodologies are an exception because of the ease of electronic monitoring. As a consequence, audit costs are also much lower there than in other sectors. By contrast, for the methodology for soil carbon, for example, samples must be taken from multiple locations, at specified depths, at regular intervals, and by certified researchers. All respondents indicated that these more complex monitoringand-reporting requirements are manageable, but that farmers need help from their carbon agents to comply with them. As a consequence, carbon agents work with their clients throughout the entire project. As one carbon agent put it: 'We are in a long term relationship with our clients, as these contracts run for ten years. That is why the relationship gets very personal.'

In 2014, the Climate Change Authority made the point that the administrative burden of project in this sector cannot easily be reduced: agricultural emissions are difficult to regulate, and hence transaction costs will remain high. ${ }^{170}$ Complicated methods are needed to ensure that abatement is real and additional. High levels of local variability make it challenging to verify emission reductions in natural systems. "These challenges are exacerbated where projects only achieve a small quantity of emission reductions, as transaction costs can become high on a per tonne $\mathrm{CO}_{2}$-e basis. ${ }^{171}$

170 Climate Change Authority, supra note 110, at 46.

171 Ibid. 
A respondent from a farmers' organization acknowledged these findings: 'the administrative burden is too big and too costly for a lot of people'. The respondent stressed the need to streamline the administration of the scheme by using automated devices, tracking devices, digitized reporting, etc. This would make the process easier for farmers as well as for the government, for the authorities could then link project systems to their own automated reporting systems: 'There still is a lot of work to do to streamline and digitalize back-end processes.'

Everyone interviewed stressed that the strict rules on registration, monitoring, reporting, and auditing are essential for the success of the scheme. The rules have led to a high degree of integrity and reliability.172 Carbon agents all acknowledged that while the thorough processes associated with each stage lead to high overhead costs for all involved, including the government, it is the price that must be paid for the reliability of a scheme that spends large amounts of public money.

\subsubsection{Scope of the Projects: Method Aims \\ 4.3.6.1 Development of Methodology Determinations for the Agricultural Sector}

Methodology development has been driven by demand and political preference. Respondents indicated that methane capture from piggeries was a method for which there was a high sector demand. Savanna burning was an important methodology because politicians wanted to favour aboriginal communities (one-third of savanna burning is done by aboriginal groups on native-title land).

Respondents at the CER said that most projects under the ERF are run by farmers, albeit they are mostly in the vegetation category, with only a small percentage in the category of agriculture. Since there are nine methodologies in the latter category, more agricultural (i.e. non-vegetation) projects had been expected to be taken up: 'It is, however, the market that decides. We have the methods; it is up to the market to propose projects.' The reason why piggeries have done well in the agriculture category is that, for biogas projects, the additionality is relatively clear, reductions are easy to monitor and measure, and the projects generate good side-benefits (lower energy bills and revenue from delivery of surplus energy to the grid). Australia Pork's respondent explained how the organization found a low-cost biogas technology in New Zealand, promoted its adoption to its members, and then promoted the adoption of a CFI methodology based on that technology to the government. The aim was

172 In 2014, the Climate Change Authority reached the same conclusion; ibid., at 2. 
a sector-wide goal of emitting no more than $1 \mathrm{~kg} \mathrm{CO}_{2}$ for each kilogram of pork produced.

It is generally thought that there are numerous other agricultural activities for which successful methodologies could be developed. Several respondents indicated their concern that this is currently not happening due to a lack of initiative in the sector. A respondent from a large farmers' organization said that most attention has been focused on the early methods that make commercial sense. More methods are needed in order to achieve a larger degree of participation by Australia's farmers. Reducing methane emissions from cattle was mentioned as an example of an area where currently there is only one methodology (piggeries), but where other promising ones, aimed at better feed conversion, such as genetic selection and changing the gut bacteria in cattle, are in the pipeline. These could become available in $3-5$ years.

As already stated, most implemented projects are in the category of vegetation. Vegetation projects are generally carried out on farmland and are mostly proposed by a handful of aggregators. One of these aggregators estimated that of all savanna-burning, vegetation-regeneration, revegetation, and soil-carbon projects, 300 to 400 (the vast majority of them) are farmland projects.

There are mixed views on whether the various methodologies are innovative. According to several carbon agents and a climate change NGO, some methodologies are too conservative, aiming at introducing technologies that farmers should introduce anyway. This may be particularly true of methodologies that were proposed by the relevant sector organization, rather than by the government or by carbon agents. There is also a timing issue: a new technology, stimulated by the CFI, over time comes into common use. Biogas production in piggeries was mentioned in this connection by carbon agents, a representative of a climate change NGO, and a former high official of the Australian government: 'Piggery farms make a lot of money by producing energy from methane. They do not need a government subsidy. Many piggeries have converted to this already simply because of economic reasons, not because of the ERF.'

However, other methodologies are new and untested. All carbon agents interviewed considered that such methodologies are risky because, at the time of adoption, it was not clear how much abatement would be generated, or whether any abatement would be generated at all, when applying the methodology in a range of different circumstances across Australia. One carbon agent estimated that about twenty per cent of the projects do not generate the level of abatement that was expected when the methodology was adopted: 'You can criticize this for not being perfect. But this was a good choice, because at least things could get started. While monitoring, we are learning.' Several carbon agents mentioned soil carbon, which is being promoted by the ERF, as a very 
promising methodology for the future. They praised the government for taking the risk of adopting a methodology for which additionality had not been fully proven. They argued that innovation has thus been assisted and that a continuous monitoring process leads to an improved methodology, potentially valuable for the whole world.

\subsubsection{Mitigation or Climate-Smart Agriculture?}

The CER respondents were clear about the goal of the ERF. This passage reinforces some of the points made earlier:

The ERF's aim is to achieve abatement at the lowest cost, it is not a grant scheme aimed at technology investment support. We have other programmes for that. It was an explicit decision to get abatement at the lowest cost. The rest is collateral. Decisions are taken purely on price. In an auction, we do not even see the projects. We only see the price and the amount of abatement, so the nature of the projects does not play a role.

Other respondents stressed that adaptation is essential for Australia's farming sector, a vital element of any sustainable farming business. Several sequestration methodologies have strong positive adaptation side effects, as they increase the resilience of the land and lead to greater efficiency. Interviewees said that increasing soil carbon is a good example of how mitigation and adaptation go hand-in-hand. Many argued for the adoption of more methodologies that have co-benefits in the area of adaptation. They felt that adaptation should play a larger role under the ERF in the future, and that the ERF should not focus on mitigation alone (see also Section 4.3.8).

\subsubsection{Results of CFI/ERF for the Environment and for the Individual Farmer}

In literature, the repeal of the Clean Energy Act and the transition from the CFI to the ERF have been criticized for a lack of ambition to achieve major cuts in greenhouse gas emissions. ${ }^{173}$ Yet this policy change did have a very positive impact on promoting carbon farming. Everyone interviewed considered the ERF a great success, at least for the agricultural sector. Abatement has been primarily achieved through vegetation projects. There is no evidence that these

173 Climate Change Authority, supra note 9, at 8 and 10 (albeit rather implicitly); Marcia Rocha, Bill Hare, Paola Parra, Jasmin Cantzler, Niklas Höhne, Louise Jeffery, Ryan Alexander, Lindee Wong, Karlien Wouters, and Kornelis Blok, Australia Set to Overshoot its 2030 Target by Large Margin (Climate Action Tracker, Climate Analytics, 2015), at 12. 
projects would have occurred anyway. The financial incentives offered by the CFI and ERF are considered to be largely responsible for the significant abatement that has been achieved in this sector. Contrary to a recent report that argues that many 'anyway'-projects are accepted under the ERF, ${ }^{174} \mathrm{I}$ found no clear evidence of this in the interviews, perhaps with the exception of a subset of methane-conversion piggery projects. As already mentioned, in that sector, some producers save AU $\$ 15,000$ (about US $\$ 11,500$ ) per month on energy bills, and earn an additional AU $\$ 15,000$ for delivering energy to the grid after having adopted methane-capture and biogas-production technology. When asked whether the CFI/ERF income or the expected economic co-benefit was the greatest attraction, the pork-sector respondent said that the CFI/ERF was the main driver for the spread of this technology:

About half of the participating producers were pushed by the CFI/ERF. It especially pushes medium sized producers, because it increases their payback just enough to get involved.

Some carbon agents, however, suggested that the large additional earnings in the piggeries sector mentioned above take away the need for the government to finance the adoption of methane-capture technologies through the ERF. It indeed seems that, over time, continued support for mitigation technologies should be reviewed. Once regular market incentives become strong enough for farmers to adopt new technologies, government funds are better directed to stimulate the adoption of innovative technologies or practices that need an additional incentive.

Continued support for methodologies should also be reviewed in the light of negative side effects on the environment. Several respondents, both carbon agents and from the agricultural sector, indicated that some methodologies, such as oil-mallee plantings, have detrimental impacts on biodiversity. When such negative side effects are discovered, it seems appropriate for the government to end its support for the methodology under the carbon-farming scheme.

174 Paul J. Burke, 'Undermined by Adverse Selection: Australia's Direct Action Abatement Subsidies' (Working Paper Series No. 1605, Centre for Climate Economics and Policy, Australian National University, 2016). This paper assumes, based on literature research, that by using an automated system when selecting projects under an ERF auction that only focuses on achieving the most abatement at the lowest cost, cheap and simple projects are favoured. 
Generally, respondents heralded the generation of new knowledge for the farming sector through the ERF. They considered that innovation was fostered by several methodologies, such as those for soil-carbon. Better farming methods are being introduced thanks to the ERF in a generally conservative sector. The methods are beneficial not only for combatting climate change - they have many benefits for farmers and even for food security. Vegetation projects generally reduce salination and erosion and improve water retention. Soilcarbon projects were described as having a remarkable impact on soil quality. One carbon agent maintained that every $1 \%$ increase in soil organic carbon leads to an increase of 14.4 litres of water availability per square metre in the top 30 centimetres of soil. ${ }^{175}$ Assessing the impact of soil-carbon projects, however, is complex, and carbon agents indicated that 'we are still learning how to do it under different circumstances'. Since the ERF requires farmers to carefully monitor what is happening in the soil, more data will gradually become available on the impact of soil-carbon increases on the productivity of the soil.

\subsubsection{Future Production Increases and Additional Emission Cuts: What Role for the CFI/ERF? \\ 4.3.8.1 Financing Carbon Farming: Private Carbon Market or Government Scheme?}

There is considerable debate about the future of Australia's climate policy and the role of the CFI/ERF as part of that policy. ${ }^{176}$ The interviews for this study were held only one month before the 2016 Australian national elections. Most respondents mentioned as important the adoption of the Paris Agreement, which necessitates a more ambitious climate policy for Australia, and the expected dramatic increase in demand for food products from Asia. These two factors call for a much stronger focus of climate policy and law on the agricultural sector.

Several respondents argued that an ETS is needed in order to generate more funds to invest in offsets from agriculture. Funding so many agricultural emission-reduction projects through government funds is unattainable, in their view. One respondent said: 'We have to go back to the original scheme of

\footnotetext{
175 I could not find confirmation of these figures, but the literature does confirm that increasing soil carbon greatly improves plant water availability. See Section 2, above, and the references in note 45 .

176 E.g. Gabrielle Chan, 'Election 2016: Turnbull Tells Leaders' Debate He Will Meet Tough Climate Change Targets', The Guardian, 29 May 2016, <www.theguardian.com/australia -news/2016/may/29/election-2016-turnbull-tells-leaders-debate-he-will-meet-tough-cli mate-change-targets $>$.
} 
the CFI embedded in a market-based cap-and-trade system.' Another consultant emphasized that setting a cap on emissions is urgently required:

Otherwise it is a bucket with a hole. It is impossible to know whether emission cuts under the ERF are additional. You have to set a cap and then introduce mechanisms like these, so that you know that overall emissions will go down. We need complementary policies therefore.

Most carbon agents expected that the Australian government would commit to additional funding for the next few years, with the aim to fund between 2,000 and 3,000 projects through to 2025. All acknowledged that, beyond that date, additional measures would be required, including setting a cap on agricultural emissions. One respondent from the agricultural business sector complained that increasing competition for diminishing ERF funds may squeeze out farming businesses. He indicated that some farmers already ask themselves 'What's the point in applying?' As far as the near future is concerned, the CER interviewees indicated that sufficient funds will be available: 'At the moment [after the April 2016 auction], we have AU $\$ 800$ million left. This is sufficient money for many more projects. Whether more money should go into the ERF is a hotly contested policy issue. They pointed out that some projects go ahead without government funding, as ACCUs can be sold in the regular carbon market.

Several interviewees - both carbon agents and representatives from agricultural organizations - were critical of the idea of having an ETs to finance carbon farming. They pointed to the current low carbon price and said that farmers need a reliable and stable source of income. A respondent from the government and academia added that it would be difficult for Australia to return to an ETS. This instrument was meant to achieve all climate policy goals at once without any additional instruments. Instead, now, a multi-instrument scheme is needed, including one focused on farmers.

The CER respondents referred to different views in the public debate, some in favour of tighter safeguards (see 'safeguard mechanism', Section 3.2.3) partly to be met by the use of tradable permits, including offsets from farmers, ${ }^{177}$ others in favour of tightening the safeguards after 2020 using emission-intensity benchmarks to create greater demand. ${ }^{178}$

177 Tony Wood, 'Road map Points Way to Stable Climate Policy', Grattan Institute website (11 April 2016), <https://grattan.edu.au/news/road-map-points-way-to-stable-climate -policy>. The Grattan Institute is an independent think-tank on Australian public policy.

178 Greg Hunt, 'Safeguard Mechanism Will Support Emissions Reduction', Media Release (6 April 2016), <www.environment.gov.au/minister/hunt/2016/mr20160406a.html>, and 


\subsubsection{Broadening the Scheme beyond Mitigation?}

As stated earlier, most respondents felt that the scheme should not have a sole focus on mitigation, but should be extended to also focus on adaptation, landscape restoration, and biodiversity preservation. There were many opportunities, they said, to rehabilitate farmland. The ERF offers the possibility to integrate these factors. Currently, beneficial impacts in these areas through the operation of the ERF, although unintended by policy, are important. A person from one of Australia's major farmers' organizations stressed the importance of having a balanced, integrated approach at farm level, namely several different types of measure at the farm that together form a good balance for mitigation, productivity, biodiversity conservation, and so on. All interviewees seemed to agree that broadening the scheme should not reduce its integrity.

\subsubsection{What about Food Security?}

Carbon farming can have a beneficial impact on food production. Generally, respondents believed that a broader process towards sustainable agriculture is needed in order to meet increasing demand under increasing climate change impacts. A respondent from a bank said: 'We only support smart farmers who have a good product and who can handle the responsibility of continuous improvement for sustainability and food security.' In order to reduce emissions while at the same time increasing production, the focus, according to a respondent from a farmers' organization, should be on reducing the emission intensity of production. This is especially important for the cattle sector, as most of agricultural emissions in Australia are associated with it: 'Reduce the emissions per beast. This is a critical part of the story. We need much more R\&D to achieve a better feed conversion.' This is in line with earlier findings of the Climate Change Authority that noted that it is likely that emissions from the agricultural sector will grow, even with a high carbon price in place. ${ }^{179}$ Although agricultural emissions can be reduced by improved manure management, feed supplement, feedlot finishing, and pasture improvements, the Climate Change Authority found that most of the technologies and practices that would achieve this are still in development and not ready for commercial use. ${ }^{180}$

Most respondents considered that the expected increase in food demand from the Asian market could in theory be met by the Australian farming sector.

$<$ www.environment.gov.au/climate-change/emissions-reduction-fund/about/safeguard -mechanism>. Greg Hunt, at the time, was the federal Minister for the Environment.

179 Climate Change Authority, supra note 108, at 54; and Climate Change Authority, supra note 9 , at 303 .

180 Ibid. 
Some increase is possible through better practices on existing farms, but the vast majority of additional food must come from yet-to-be-developed agricultural areas. In the tropical north of Australia, especially, there are areas with good irrigation potential, such as the Pilbara Region. Development of this area is currently being discussed, as is evident from a 2015 government White Paper. ${ }^{181}$ Through the new Northern Australia Infrastructure Facility Act 2016, the federal government offers up to $\mathrm{AU} \$ 5$ billion (Us $\$ 3.8$ billion) in concessional loans to encourage and complement private-sector investment in economic infrastructure in northern Australia, so that agribusiness can be further developed there. Basic infrastructure is needed, such as port facilities. The big question, according one carbon agent, is whether environmental protection will keep up with the increase in production. A former government official was highly critical of these developments in northern Australia and suggested that it was an excuse to clear land. He referred to the 2015 CSIRo National Outlook, which argues that with a minimal carbon price, current agricultural lands will be more productive. ${ }^{182}$ According to the former official, increasing soil carbon is much more valuable than beef cattle land. He also argued that the focus should be on changing human diet: 'Are we certain that Asians, as they get richer, want beef?' He referred to the development of high-protein plant-based food products that are currently being developed and will become commercially available soon, especially in the Netherlands and the United States:

To produce these plant-based proteins, much less land is needed, and it gives you much of what is required by richer people who want proteinrich food. A diet change is needed to accommodate the increase in food demand and reduce emissions from agriculture. Agricultural countries like the Netherlands and Australia will remain agricultural countries, but

181 Australian Government, 'Our North, Our Future: White Paper on Developing Northern Australia' (Canberra: Commonwealth of Australia, 2015), at 56: 'The north could become an agricultural powerhouse — on par with Brazil's Cerrado—and be recognised globally as a leading region in high quality food production. Reforms to land tenure and improved land surveys could open up a quarter of the north's land area-equivalent to half the size of New South Wales—for new development opportunities.'

182 CSIRo, Australian National Outlook 2015: Living Standards, Resource Use, Environmental Performance and Economic Activity, 1970-2050 (Canberra, Australia: CsIro, 2015), at iii. The report concludes: 'At payments for carbon farming around A $\$ 40-60$ per tonne of $\mathrm{CO}_{2} \mathrm{e}$ by 2030, carbon credits could be harnessed to reward landowners for restoring ecosystems, increasing native habitat by $17 \%$ and decreasing extinction risks by $10 \%$, without large additional government outlays.' 
can produce more with fewer resources. Farmers will have to grow different things. ${ }^{183}$

\subsection{Conclusions from Empirical Research}

A wealth of information was collected in the case studies and interviews. The following main conclusions can be drawn from the empirical research into Australia's CFI:

1. The regulatory framework laid down in the CFI Act and associated regulations is considered robust and ensures integrity.

2. Consultants have been the main drivers of the scheme, with associated costs for farmers. Sector organizations play an important role in persuading individual farmers to engage in carbon-farming projects.

3. The monitoring, reporting, and verification (MRV) processes are usually run by consultants because of their complexity, which increases costs for farmers. Only where automated/digitized systems exist can farmers manage MRV themselves. Research into and development of such automated monitoring and reporting systems across methodologies is needed.

4. There seems to be a high level of compliance, although checking for compliance, so far, is mainly done on the basis of audit reports. ${ }^{184}$

5. Although many different carbon-farming methodologies have been adopted, only a few are applied in the farming sector. This is primarily because of the scheme's focus on achieving the largest possible amount of abatement for the lowest cost; to a lesser degree, it is due to a lack of interest by certain influential agribusiness organizations.

6. The level of ambition is not the same for all methodologies: some are considered to be too similar to what farmers are expected to do anyway because the market already offers large economic incentives to do so, while others are considered to promote innovation.

7. Those methodologies that have important co-benefits for farmers, for food security, and for the broader environment, are heralded as important

183 A range of start-up companies is developing meat-like products from plants; for an overview, see Anonymous, 'Silicon Valley Gets a Taste for Food', The Economist, 7 March 2015, $<$ www.economist.com/news/technology-quarterly/21645497-tech-startups-are-moving -food-business-make-sustainable-versions-meat $>$.

184 Recent research shows that this is risky and that enforcement agencies should also develop their own inspection policy and carry out, for instance, site visits; Jonathan Verschuuren and Floor Fleurke, 'Enforcement of the EU ETS in the Member States', 1-2 ELNI Review (2015) 17-23. 
instruments for change. The focus should be on adopting methodologies that have such co-benefits and are not about mitigation alone. A considerable effort of research and development is needed to develop reliable methodologies that foster innovation in all agricultural sectors.

8. The switch from a purely market-based mechanism to a mechanism under which the government buys up credits for a fixed price under a longterm contract drafted prior to abatement being delivered has given an enormous boost to the adoption of carbon-farming practices in Australia.

9. In order to also engage the large majority of smaller farms, it is necessary to adopt a 'whole of farm' approach that allows farmers to adopt a set of different measures under different methodologies without the need to divide these activities into separate ERF projects, with all of their associated administration costs.

10. The expected large increase in global food demand will lead to higher emissions that are difficult to reduce with schemes like the ERF alone. In the long run, a dietary change away from meat products is suggested as the ultimate way to drastically reduce emissions from agriculture.

\section{Conclusion: Lessons for Regulatory Design Aimed at Reducing Emissions from Agriculture}

This article has reviewed the experience with Australia's carbon-farming legislation, with the objective to articulate lessons for regulatory design aimed at reducing greenhouse gas emissions from agriculture. Both the desk study and the empirical research presented above lead to the conclusion that Australia's Carbon Credits (Carbon Farming Initiative) Act 2011 provides an elaborate legal framework that seems well-suited to assess project applications and issue credits to participating farmers who, through such approved projects, generate real and additional emission reductions. The 2015 amendments leading to the creation of the ERF increased participation by farmers by reducing uncertainty about the revenue to be generated from the projects. The experiences in Australia form a reliable basis for recommendations to policymakers and regulators from around the world who wish to develop a regulatory framework aimed at stimulating farmers to adopt farming practices that reduce greenhouse gas emissions or broaden climate-smart practices.

The following lessons may be drawn.

The first and possibly most important lesson is not a purely legal one. A policy aimed at stimulating carbon farming has to be reliable and provide certainty for at least ten or even twenty years ahead. Farmers who adopt carbon 
farming must implement structural changes to their farming practices which have long-term impacts on their business. The policy environment as well as the financial environment of agribusiness must accommodate such long-term impacts. This implies that relying on the carbon market for funding should only be done when there is a long-term certainty that carbon credits will earn an acceptable minimum price.

The next lesson also concerns the broader policy background. A policy that has a wider focus on adaptation, food security, resilient and sustainable farm businesses, and securing and creating jobs in the agribusiness sector is likely to be more successful than one that only focuses on reducing emissions from agriculture. Several of the methods that have been accepted or are under development in Australia, such as those dealing with soil carbon, show that such co-benefits can indeed be achieved.

Developing climate-smart methodologies that not only deliver real, additional, measurable, and verifiable emission reductions but also foster longterm innovation and create economic, social, and environmental co-benefits is essential for the success of any policy aimed at stimulating climate-smart agriculture. Science has to be central in the development and adoption of methods that are accepted under the regulatory framework. In Australia, much research effort has already gone into the development of methodologies. International collaboration in methodology development is important for efficiency reasons. When developing methodologies, special attention must be paid to small farms.

Regulation should focus on projects and should not set uniform rules or simply require farmers to hand in allowances under an ETs. Given the fact that potentially large numbers of farmers should be able to participate, much of the attention must be focused on developing automated systems for all phases of the process: from project application through to monitoring, reporting, and verification. Project development according to accepted methods needs to be guided by experts. Agribusiness organizations have a role to play here, but most work will be done by the private (consultancy) sector.

Having a robust and reliable MRV system in place is, as with the ETS, essential. The regulatory framework will have to comprise detailed legal rules on MRV. By contrast with most sectors, in agriculture, MRV is very site-specific and can be labour-intensive, especially in the case of carbon sequestration. Again, private consultancy businesses will have to play a major role here. Research is needed to develop reliable and less labour-intensive methods to assess the amount of emission reductions achieved or carbon sequestered.

Despite its fairly weak overall climate change policy, Australia has shown that it is possible to regulate for the reduction of emissions from agriculture 
and for increased carbon sequestration in agricultural soil and vegetation on agricultural lands. In order to achieve the Paris Agreement's objectives, the rest of the world must rapidly start developing policies and laws to unlock the potential of the agricultural sector, so that climate-smart agricultural practices are commonplace before production levels increase following the expected dramatic increase in demand for food products. 